\title{
9. 新エネルギー源
}

\subsection{MHD 発電の動向}

\section{1. オープンサイクルMHD発電の研究開発}

オープンサイクルMHD発電の研究開発は, 最大の 懸案であった発電チャネルの耐久性に関して見通しが 得られるようになり，大型装置による実験段階を迎克 ている。わが国においては工業技術院のムーンライト 計画に扮いて，EＴＬマーク７発電機の運転実験が行 われている。米国においては CDIF, CFFF, HPDE などの大型実験が開始されたものの, 予算削減のため, 現行揖よび次段階以降の研究計画などが再検討されて いる。 ソ連に拈いては1986 年頃の運開を目標に出力 $500 \mathrm{MW}$ の商用機（U-500）の建設がなされている。 その他中国，インドなどに拀いても積極的永研究開発 がなされている。

(1) 日本

昭和51年度から昭和57年度までの予定で行われてい るMHD発電研究開発第 II 期計画では，100kW，200時 間を目標としたE T L マーク 7 の建設揖よび運転研究 がなされている。マーク 7 の基本構成等はすでに本誌 で紹介されて扮り，ここでは省略するが，表 9-1 と昭 和56年度に行われた運転結果を示す。

昭和56年 7 月に全システムの調整，燃焼性能，脱硝 性能テストをかねてRun 1 の発電実験が行われた。こ の実験で使用された発電チャネル $\mathrm{A} は, \mathrm{Al}_{2} \mathrm{O}_{3}$ コーテ ィング・ペグ絶縁壁と水冷電極（陽極 S U S -304, 陰 極 $\mathrm{Cu}-\mathrm{W}$ ) で構成されている。ファラデー結線におい て119kW，ダイアゴナル結線で $87 \mathrm{~kW}$ の出力が得られ， 設計計算通りの性能が得られる事が確認された。
さらに長時間耐久試験のため，絶縁基板の改良，目 地部の改良，白金電極の採用，電流分散法の採用など の改良が加兄られた発電チャネルBが製作され，同年 10月 (Run 2)，11月（Run 3） 飞発電実験が行われ た。Run 2 では，出力变動，開放電圧，短絡電流，ガ

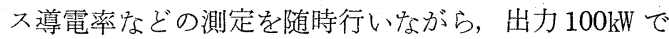
連続運転を行ったが，発電チャネル以降の後流機器の トラブルで実験後 157 時間で一旦運転を停止した。実 験後の発電チャネルは良好でめったので，そのままの 状態で, 下流機器の補修後 Run 3 の発電実験を行っ た。Run 3 \& Run 2 と同じ条件で発電運転を継続し たが，実験開始後67時間でディフューザ下流の煙道で 水漏孔が生じたため，熱入力を下げ運転を継続し，運 転時間累計 200 時間招よび出力 $20,000 \mathrm{kWh}$ の目標を 越兄る発電を達成し耐久試験を終了した。実験後の損 傷も局所的なものは見られず，電極材の損耗は 0.2 $1.3 \mu \mathrm{g} / \mathrm{C}$ 程度であり, この構造のチャネルで 1,000 時 間程度の寿命が推定されている。

またマーク 7 は石油燃焼による発電実験であるが， 将来の燃料としては石炭しかなく, 石炭燃焼MHD発 電の基礎的研究が電子技術総合研究所括よび北海道大 学, 豊橋技術科学大学, 京都大学などで行われている。

ムーンライト計画による第II 期計画は昭和57年度に 終了する予定であり，その後の開発計画を立案するた め, 昭和 55 年 2 月に「MHD 計画検討小委員会」が MHD発電分科会の下に設立され，マーク 7 の成果お よび各国の開発情況をふ心克，拈拈む权 2 年後に意志 決定を行うよう提言がなされていた。現在，第II 期計 画の最終年に施たり，上記委員会が再会され，国際協 力も含めた次期計画の検討がなされている。

表 9-1 E T L マーク 7の実験結果

\begin{tabular}{|c|c|c|c|c|c|}
\hline 実 験 No. & 設 計 & Run 1 & Run 2 & Run 3 & $\begin{array}{c}\text { Bチャネル } \\
\text { 合 計 }\end{array}$ \\
\hline 発電 チャネル & - & A & $\mathrm{B}$ & $\mathrm{B}$ & $\mathrm{B}$ \\
\hline 燃 焼 時 間 $(\mathrm{hr})$ & - & 90 & 157 & 119.5 & 276.5 \\
\hline 発 電 時 間 $(h r)$ & 200 & 13 & 128 & 99 & 227 \\
\hline 発 電 電 力 量 $(\mathrm{kWh})$ & 20,000 & 470 & 12,460 & 8,374 & 20,834 \\
\hline 定格時での平均出力 $(\mathrm{kW})$ & 100 & 一 & 100.1 & 96.0 & 98.9 \\
\hline
\end{tabular}


(2) 米国

米国の開発計画は, 1990年代前 半に出力 $200 \mathrm{MW}$ の実証プラント

（E T F）を建設・運転する事に あった。このため, 1977 年から 1981年の 5 年間に 3.7 億ドル（約 900 億円）のD O E 資金が投入さ れ, $\mathrm{CDIF}, \mathrm{CFFF}$ などの大型装 置が建設された。しかし1981年の レーガン政権の 誕生以来, 図 9-1 に示すように開発資金が激減し, きわめて不安定な状態におかれて いる。これはMHD発電技術が石 炭利用技術の中にあり, 実用化が 間近い技術は民間資金で行らべき

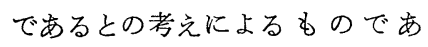
る。しかしMHD発電技術は未だ 民間資金を投入するにはリスクが 大きい技術であり，このため電力 会社, メーカなどがそれぞれ団 体注）を作り,政府資金による開発 プロジェクトの継続を議会を通じ て強く働きかけるとともに, 政府 資金により開発すべき目標值の検

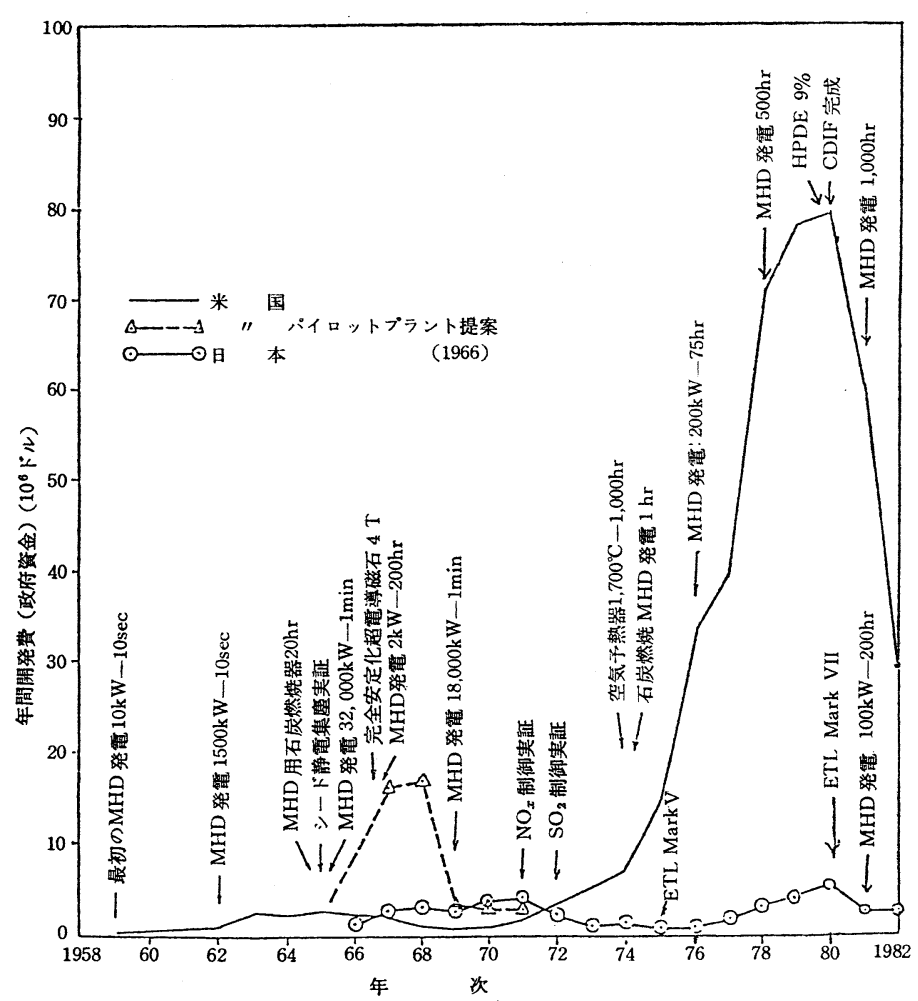

図 9-1 M H D開発の過程と費用

討, 開発計画の提案など, 積極的な活動がなされてい る。いずれにしろ，下記の上らな順調な開発成果にも かかわらず，資金難といら事情のため，1990年代前半 の商用化という基本計画は遅れるものと思われる。

CDIF は現在の研究開発の中心となる装置であり, 石炭燃焼器, 発電チャネルなどの主要構成機器を順次 接続しテストする事を目的としている。現在は熱入力 $50 \mathrm{MW}$ の石油燃焼器 (石炭灰を添加し石炭模擬燃焼), 超音速発電チャネル，銅鉄磁石の組み合わせで実験が なされており, 設計出力 $2 \mathrm{MW}$ 対し710kWの出力が得 られている。

注) (1) National MHD Users Group 主要電力会社 14 社をメンバーとし, 全米発電 設備の70\%以上をカバーする電力会社団体。

(2) Edison Electric Institute MHD Users Group 15電力会社よりなる団体

(3) MHD Industrial Forum $\mathrm{GE}, \mathrm{WH}$ を含む17社のメーカ団体

(4) Western Utilities Chief Executive Officer Conference 西部16電力会社の社長会

CFFFは輻射ボイラーなどの後流機器を開発する事 を目的として拈り, 直接微粉炭燃焼も可能な装置であ る。現在までに熱入力 $28 \mathrm{MW}$ に拈いて, 輻射ボイラー でのガス制御を行う事により, 排出 $\mathrm{NO}_{x}, \mathrm{SO}_{x}$ の制 御実験がなされ，排出基準值を達成出来る事を示した。 HPDE は熱入力 $250 \mathrm{MW}$, 出力 $40 \mathrm{MW}$, 時間10秒の 発電装置であり, 商用化に必要な発電チャネルの変換 効率15\%以上を実証する事を目的としている。現在ま でに出力 $28 \mathrm{MW}$, 効率10.5\%が得られ, 今後磁界を $6 \mathrm{~T}$ 程度に上げる事により目標値を達成出来る見通しが得 られている。

特筆すべきはAVCO 社の Mark VIにおいて, 現在 まで最大の課題であった，発電チャネルの耐久性に関 して，8,000 時間程度の見通しが得られた事である。 AVCO 社は MHD 発電の研究開発で々最先端の民間 会社であり多くの成果を出して来た。現在 Mark Vで は200kW，100時間（1976年）５00時間（1978年）運転 に続き亜音速チャネル, 出力制御方式の研究開発を行 っている。Mark VII では上記成果をふま克, 図9-2に 示すような電極構造の発電チャネルを製作し 1,000 時 間耐久試験がなされた。電気出力は $55 \mathrm{~kW}$ とさいが, 


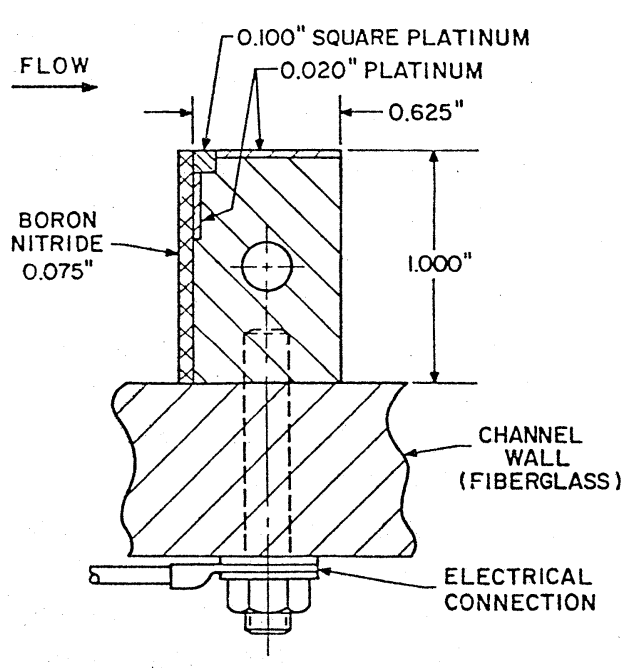

CONFIGURATION NO. 1

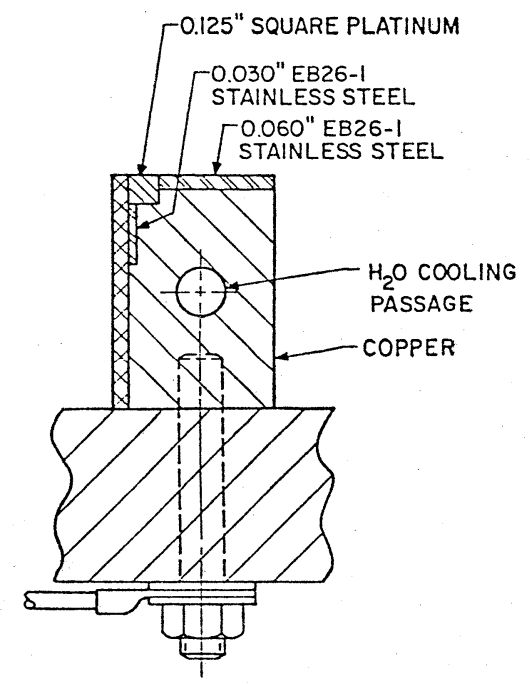

CONFIGURATION NO. 2

図 9-2 MHD 陽 極構造

電流, 電圧条件は商用機を模擬している。実験後の損 耗率は $0.11 \sim 0.24 \mu \mathrm{g} / \mathrm{C}$ であり，この結果を外捜する と約 7,500 時間の寿命が得られる。現在チャネルを修 復せずにさらに 1,000 時間, 累計 2,000 時間の耐久試験 が計画されている。

発電チャネル以外のコンポーネントの開発も行われ ており, 石炭然焼器については T RW 社が熱入力 20 MWの装置を完成し，また超電導磁石についてはC F F F 用磁石 (6T, 172 ton) がA N で完成し, それ ぞれ所期の性能が達成された。しかし資金難のため, 次に計画されていたコンポーネントの開発が一時中止 されている。

(3) その他の国

ソ連におけるMHD発電の研究は, 世界の最先端を いっているが, 詳細な情報は得られていない。高温研 究所に沶いては, 天然ガスを然料とするMHD発電の 研究開発を行い, 出力 $20 \mathrm{MW}, 500$ 時間のU-25実験機 を成功させ，この成果をらを電力省に拈いて1986年 を目標に出力 $500 \mathrm{MW}$ の商用機が建設されている。一 方高温研究所では, 従来の装置を石炭燃焼用に改造し 石炭燃焼MHD発電の研究開発がなされている。

中国に拉ける研究は1960年代より始められ, 出力 10 〜20kWで200時間および出力590kWなどの成果が得られ ている。特に小型石油燃焼MH D一汽力複合サイクル 発電プラントを建設し，100 時間の運転を行うなど注 目すべき成果を出している。またインドにおいても熱
入力 $5 \sim 15 \mathrm{MW}$ のプラントが建設されつつある。

\section{2.クローズドサイクルM H D 発電の研究開発}

クローズドサイクルは研究が遅れているため,オー プンサイクルの次に来るものとして, 托もに大学で研 究がなされている。

希ガス非平衡MHD発電では, 電離不安定性に問題 があったが，東京工業大学に衿いて，シード率を著し く小さくする事により問題を解決出来る見通しが得ら れ，現在大型ブローダウン装置を建設中である。オラ ンダの Eindhoven 大学では, 熱入力 $5 \mathrm{MW}$ のブロー ダウン発電実験を行い, 出力 $200 \mathrm{~kW}$ を得ている。この よらに希ガスMHD発電の理解はかなり進んで来た。

液体金属MHD発電の研究は，さらに基礎的な研究 となっている。わが国においては筑波大学において $\mathrm{NaK}$ のブローダウン装置により, 理論解析と運転実 験がなされている。海外においてはアメリカ, ソ連お よびイスラェルに拈いて発電寒験が行われている。

\section{文献}

1) 19th Symposium on Engineering Aspects of MHD, June 15-17, 1981

2) Specialists Meeting on Coal Fired MHD Power Generation, November 4-6, 1981 


\section{2 地熱発電の動向}

\section{1. わが国の現状}

わが国には現在（昭和56年12月末） 6 地熱発電所が ある。三菱金属秼の大沼発電所 (秋田県), 日本重化学 工業秼の松川発電所, 東北電力脷の葛根田発電所 (共 飞岩手県), 電源開発(秼)の鬼首発電所(宮城県), および 九州電力侏の大岳発電所・八丁原発電所 (共に大分県) がそれらである。以上の他，ごく小規模のものとして は大分県別府にある杉乃井ホテルの自家用地熱発電所 がある。設備容量は $3,000 \mathrm{~kW}$ である。すた建設中の地 熱発電所としては北海道電力侏による北海道森町にお ける森発電所がある。その設借容量は $50,000 \mathrm{~kW} か ゙$ 予定 されており, 昭和 57 年中に運転開始さ放る予定であ る。上記の 6 発電所の 昭和 56 年の 1 年間の実績は表 9-2 に掲げられてある通りである。前年の発電電力量は $1,105 \times 10^{6} \mathrm{kWh}$ であったが，これと比較して汪とん ぞ同じ電力量であった。また稼働率がきわめて高いと いら地熱発電の特色が示されている。

\section{2. 海外の動向}

表 9-3 に世界の地熱発電の現沉を揭げた。総設備容 量は大略 2,500MW に達する。世界で最もはじめに地 熱発電がはじめられたのはイタリアに执いてであり, その歴史は小規模の発電であるが今世紀のはじめ頃に さかのぼることができる。そして最近までその設備容 量に求いて久しく世界の首位をしめていたが，近年ア メリカにその座をゆずった。またここ数年来フイリッ
ピンにおける発展がめざましく遂にアメリカについで 第 2 位になった。アメリカの容量は世界の約 $37 \%$ に

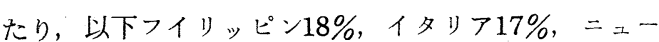
ジーランド $8 \%$, 日本 $7 \%$ の順となる。日本では先述 のように 1982 年に北海道の森地熱発電所 $(50,000 \mathrm{~kW})$ が運転を開始する予定であり，これが穾現すればニュ ージーランドを抜くことになる。フイリッピンにおけ る開発にはアメリカの企業進出があるが，フイリッピ ンをその例とするような，石油資源に恵まれない発展 途上国に対し，先進国からの技術援助，技術進出は今 後益々盛んに行われるるのと考兄られる。

\section{3. 地熱調査活動}

昭和55年設立された新エネルギー総合開発機構は, 石油代替エネルギーの開発および導入の促進に関する 法律に基づく，わが国の代替エネルギ一開発の中核的 推進体である。その本格的活動は昭和56年からといっ てよい。本機構が通商産業省（資源エネルギー庁およ び工業技術院）よりの依託あるいは補助を受け地熱調 查を行っている。この機構が行った調查のらちボーリ ング調査を列記すると次のものをあげることができ る。

すなわち，

（1）地熱開発促進調查

1 ) 岩手県八幡平東部地域（750 1, 350m 深計 5 坑）

$2 ）$ 山形県銅山川下流地域（1,000 1, $600 \mathrm{~m}$ 深計 5 坑）

3 ）鹿児島浔栗野・手洗地域（500 1, 500m深計

表 9-2 わが 国の地熱 発電 所（渾転中のもの）

\begin{tabular}{|c|c|c|c|c|c|c|c|c|}
\hline 発 & 電 所 & 名 & $\begin{array}{c}\text { 設備容量 } \\
\mathrm{kW}\end{array}$ & $\begin{array}{c}\text { 認可容量 } \\
\text { kW }\end{array}$ & $\begin{array}{c}\text { (1) 発電電力量 } \\
\mathrm{kWh}\end{array}$ & $\begin{array}{c}\text { (2) 最大電力 } \\
\mathrm{kW}\end{array}$ & $\begin{array}{c}\text { (3)稼動率 } \\
\% \\
\%\end{array}$ & $\begin{array}{c}\text { (4) 負荷率 } \\
\%\end{array}$ \\
\hline 大 & \multirow{5}{*}{ 根 } & 沼 & 10,000 & 8,600 & $60,596,900$ & 7,700 & 95.19 & 90.0 \\
\hline 松 & & 川 & 22,000 & 22,000 & $173,976,700$ & 23,100 & 96.3 & 90.3 \\
\hline 暮 & & 田 & 50,000 & 50,000 & $336,529,000$ & 46,100 & 95.3 & 83.3 \\
\hline 鬼 & & 首 & 25,000 & 12,500 & $46,750,000$ & 8,000 & 95.6 & 66.7 \\
\hline 大 & & 岳 & 12,500 & 12,500 & $70,140,000$ & 11,650 & 94.8 & 68.7 \\
\hline 八 & 丁 & 原 & 55,000 & 55,000 & $421,699,000$ & 53,800 & 99.2 & 89.5 \\
\hline & 計 & & 174,500 & 160,600 & $1,109,691,600$ & & & \\
\hline
\end{tabular}

注) (1) 発電電力量は昭和 56 年 1 月 1 日 同年 12 月 31 日の 1 年分

(2) 最大電力は 1 時間最大

(3) 稼働率は（稼働日数 $/ 365 ） \times 100 \%$

(4) 負荷率は（筸日平均電力/最大電力) $\times 100 \%$

また，大岳発電所については昭和56年 7 月 17 日補充蒸気井O-18併入，八丁原発電所については昭和56 年11月18日補充蒸気井H一17併入，がそれぞれあった。 
表 9-3 世界の地熱発電の現況（1981年）

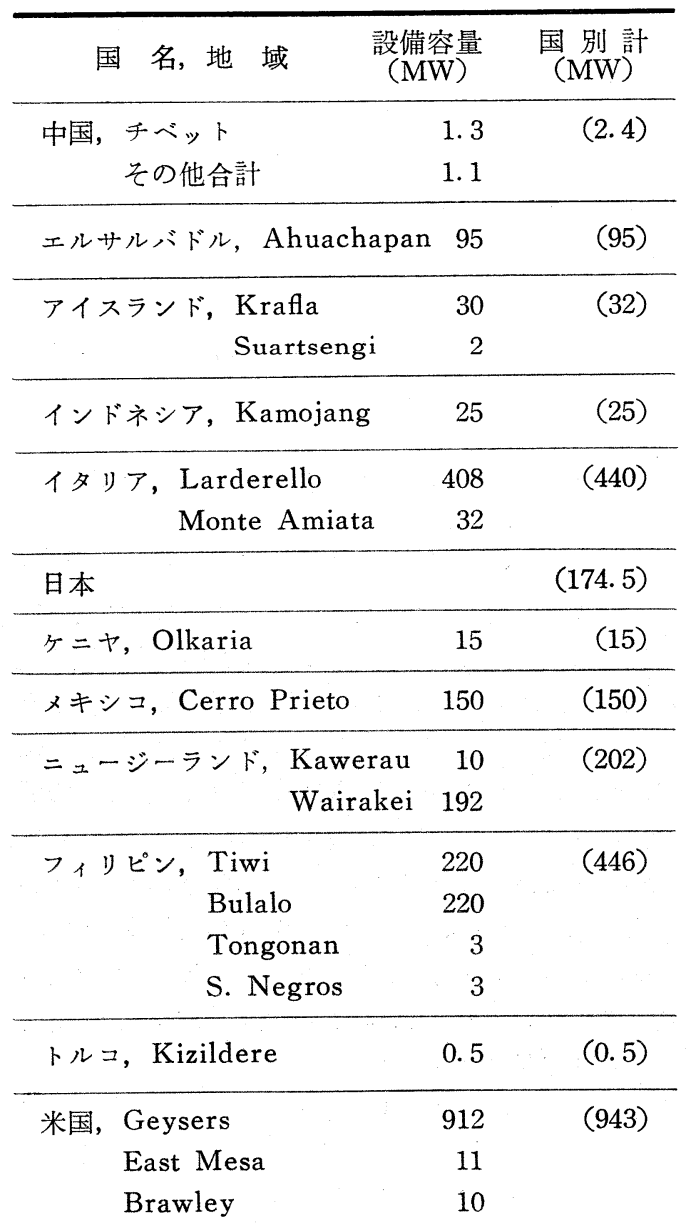

Niland 10

\begin{tabular}{lrr}
\hline ソ連, Pauzhetskii & 5 & (5) \\
\hline 計 & & $2,530.4$ \\
\hline 6 坑)
\end{tabular}

4) 北海道胆振地域 $(1,500 \sim 1,800 \mathrm{~m}$ 深計 4 坑)

5 ) 青森県沖浦地域 (500 1, 500m 深計 7 坑)

（2）深層熱水供給システム開発

1 ) 秋田県雄和地区（1,310m深 1 坑， 1, 317m 深 1 坑）

（3）大規模深部地熱発電所環境保全実証調査

1) 大分・態本県豊肥地域 $(1,500 \mathrm{~m}$ 深 1 坑，2,600 $\mathrm{m}$ 深 1 坑

国の機関以外による調査活動についてその掌握は難し いが，1981年に行われたおもなボーリング調査として 表 9-4のものをあげることができる。

\section{4. 地熱研究活動}

国の地熱開発技術の研究は通商産業省工業技術院の サンシャイン計画の一環としてとりあげられている。 そこで1981年度にとりあげられたテーマ名は次の通り であった。

(1) 地熱エネルギー探査技術

1) 地熱探查技術等検証調查

2）深部地熱資源探査技術に関する研究

3）国土地熱資源基本図作成に関する研究

(2) 地熱エネルギー採取技術

1) 高温地層掘削機器の開発

2 ）地熱井掘削技術に関する研究（高温岩石のエ

表 9-4 1981年のおもなボーリング活動（各企業体による）

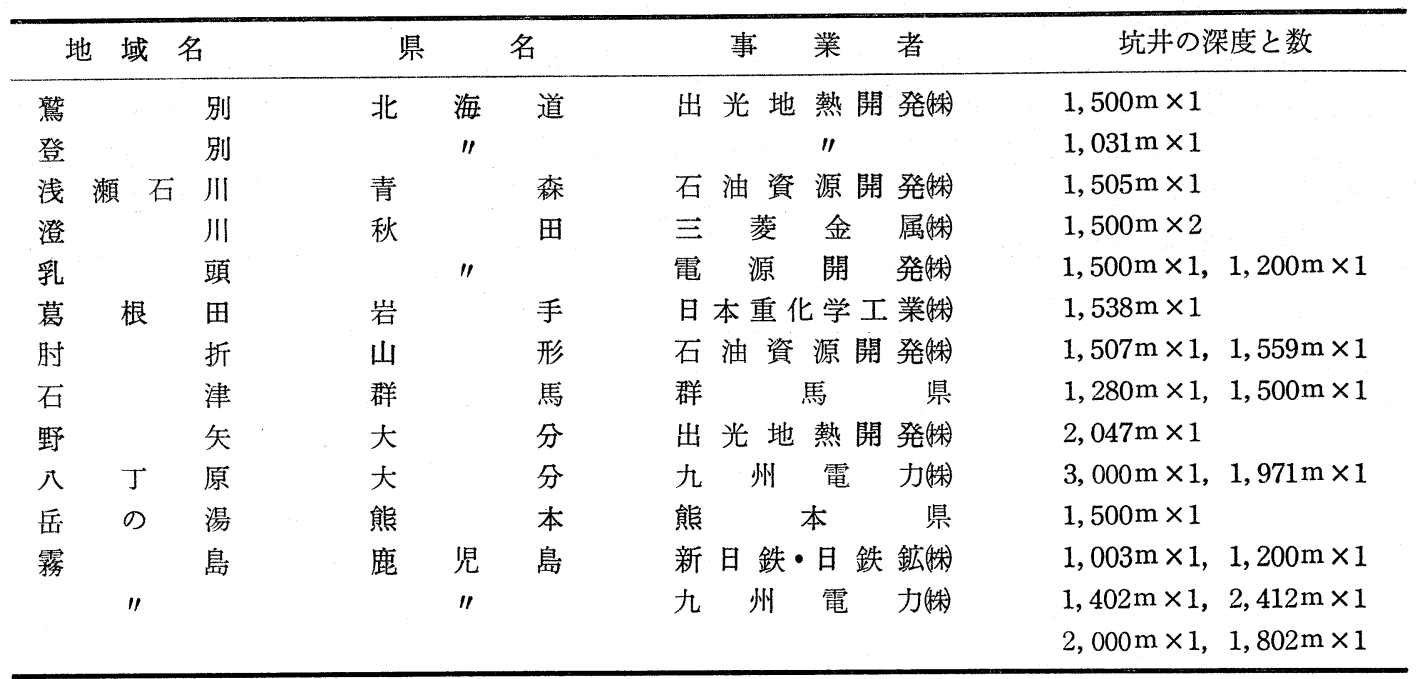


ヤードリリングに関する研究および高温高压 泥水掘削に関する研究)

3）坑井内測定技術の開発（坑井内測定技術の開 発永よびフラクチャリング技術の開発）

4 ）熱水の地下還元メカニズムの調査研究

(3) : 地熱用材料の開発に関する研究

(4) 高温岩体発電システム

1）高温岩体の破砕熱抽出技術に関する研究（岩 石力学的物性の究明, 岩体破砕機構の解明, 熱抽出機構の解明)

2）高温岩体発電方式に関するフィージビリティ スタディ

(5) 環境保全・多目的利用技術

1）地熱流体処理技術の開発（地熱熱水のスケ一 儿付着防止技術の研究開発, 硫化水素除去技 術の開発）

（6）国際エネルギー技術開発協力事業

以上がいわゆる一般会計で行われた。

（7）全国地熱資源総合調査

（8）地熱探査技術等検証調査

（9）熱水利用発電ブラントの開発

1）バイナリーサイクル発電プラントの開発

2) トータルフロー発電プラントの開発

(10) 深層熱水供給システム開発

以上はいわゆる特別会計で行われた。

以上のらち(1)の1) と(8)は同一計画であるが 2 つの会 計で行われていることを意味する。

国の研究はこの他文部省、大学などのものをはじめ 多くある。また民間の研究すさかんであるが，全体を 掌握し難いのでここでは省略する。

\section{5. 発展途上国技術者のトレイニング}

例年行われている九州大学におけるgroup training course in geothermal energy は今年も同大学工学 部小野寺清兵衛教授をコースリーダーとして行われ た。

本コースは国際協力事業団の事業としてなされるも
ので，発展途上国の技術者に対し地熱開発の技術につ いての訓練を行うものである。9月17日より11月20日 に互って行われ，次の各国より合計12名が参加した。

ブラジル, コロンビア，エジプト，インド，インド ネシア，ケニア，韓国，パキスタン，ペルー，フィリ ッピン,タイ,トルコ。

\section{3 燃料電池の動向}

東京電力秼が千葉県五井火力発電所内に建設中の直 流出力 $4.8 \mathrm{MW}$, 交流出力 $4.5 \mathrm{MW}$ 燃料電池発電プラ ントの電池本体が昭和57年 1 月に搬入され, その据え つけが 4 月に完了し，10月の発電開始に向けて調整に 入いることが報ぜられ1)，が国に和いても，燃料電 池発電方式が本格化してきていることが明らかにされ た。この燃料電池プラントは, アメリカの United Technologies Corp. (UTC) から購入したりン酸電 解液然料電池プラントで, 運転については, 三井東圧 化学秼)よび東京芝浦電気秼が協力態勢にはいってい る1)。これと同規模のプラントが New York の Manhattan 地区にも建設されているが，電池形式は東京 電力のそれよりやや古い。両者とも, 1982年秋から， ず 6,700 時間のテスト運転にはいる予定である ${ }^{1) ~ 4) ~}$ また，これとは別に，常圧運転の $40 \mathrm{~kW}$ 出力のリン酸電 解液燃料電池を単位とする On Site/Integrated Energy System (OS/IES) がアメリカで検討され, エ ネルギー省(Department of Energy-DOE) の Fuel Cell Operational Feasibility (FCOF) プログラム のなかで，1982年に， 3 個のプラントがテスト地点に 送られ，最低 8,000 時間のテストが始められることに なっているが，最終的には，45個のプラントが20〜30 地点でテストされる予定である5。 わが国でも，これ とは別に大阪ガス秼と東京ガス侏が，UTCから１基 ずつ各 60 万ドルで購入乙昭和 57 年 3 月末から試運転を

\begin{tabular}{|c|c|c|c|c|c|c|}
\hline 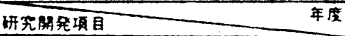 & 56 & 57 & 58 & 59 & Bo & 81 \\
\hline & & $1000 \mathrm{KW}$ & 池 & & & \\
\hline 1.リン酸型燃料䒼池 & & 要䋈研究 & 設計 & 鉧作 & & \\
\hline 2.アルカリ型然料電池 & & & & $5 \mathrm{~kW}$ & 雷池 & \\
\hline 3. 溶骮炭酸塩型然料電池 & & & $1 \mathrm{KW}$ & 神池 & $1 \mathrm{NKW}$ & 要池 \\
\hline 4. 固体㫣解質型然料曋池 & & & & $1 \mathrm{~K}$ & 投雷池 & \\
\hline 5.トータルシステムの研究 & & & & & & \\
\hline
\end{tabular}

図 9-3 ムーンライト計画燃料電池発電技術開発スケジュール 
始め，夏からフィールドテストを行らことになってい る。

わが国では，通産省工業技術院のムーンライト計画 のなかで大型省エネルギー技術研究開発の一環として 燃料電池発電技術の開発がとりあげられ，昭和56年度 から 6 年間に約 110 億円の研究開発費を投じて, リン 酸電解液燃料電池システムの開発を中心とし, 溶融炭 酸塩燃料電池, 固体電解質燃料電池およびアルカリ性 電解液燃料電池の研究開発を行らことがきめられた。 この燃料電池発電技術の開発スケジュールを図 9-3に 示すが，これらでは, 各電池本体の開発, 燃料改質系, 排熱回収系拈よび制御系などの周辺技術の開発を行 い, システムの最適化, 配置と環境, 安全性との関連, 利用法と経済性などについてトータルシステムとして の研究を行らことがきめられている6 心となるリン酸電解液燃料電池システムは, 新エネル ギー総合開発機構を通して, 富士電機製造陎，侏富士 電機総合研, 三菱電機䛈, 東京芝浦電気陎拈よび侏日 立製作所の 5 社认研究委託され, 前 3 者が, $170^{\circ} \sim 200$ ${ }^{\circ} \mathrm{C}, 2 \sim 4 \mathrm{~kg} / \mathrm{cm}^{2}$ の低温低圧型の 分散発電所用電池, 後 2 者が, $200 \sim 220^{\circ} \mathrm{C}, 6 \sim 8 \mathrm{~kg} / \mathrm{cm}^{2}$ の高温高圧型の 火力 発電代替用電池を目標として開発することになってい る7)。これらの企業は，它れぞれ20５0kW のリン酸電 解液然料電池システムを自社技術で開発してすでに発 表している8)。これらの電池はすべて水冷式であるが, 三洋電機秼では空冷式の $15 \mathrm{~kW}$ 電池を試験し, さらに大 出力電池を開発しょうとしている99。

また，中央電力協議会では技術開発推進会議内に燃 料電池技術検討作業会を設置し各社の開発状沉から電 気事業としての目標と試験項目ををとめて, 各社の燃 料電池システムの開発を推進することをきめている 10)。

アメリカでは 1979 年に構成された政府機関中心の National Fuel Cell Coordinating Group(NFCCG) （本誌 60(652)687（1981）燃料電池の動向参照）の発 足に引き続き，1980年 4 月には民間中心の Fuel Cell Users Group(FCUG) が結成され，燃料電池開発に 対する官民協力態勢ができている11)。FCUG のメン バーはアメリカ以外の各国の組織を含めて45をこえて いるが,この目的は, 燃料電池に関する情報を交換し, その開発を援助し, 燃料電池発電プラントの市場性を 調査してその商業化を促進することにあるといら。こ のよらな情勢下で, エネルギー省の解散, 商務省への 移管が大統領によって承認されているにるかかわら ず，同省が要求していた1982会計年度の燃料電池関係

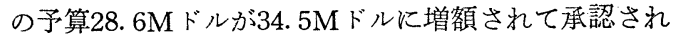
ている(2)ことからもわかるように, アメリカの然料電 池開発に対する熱意は旺盛で, National Fuel Cell Seminar も例年のごとく開催されている（6月23〜 25日 Virginia 洲の Norfolk)。なお, 燃料電池汇関

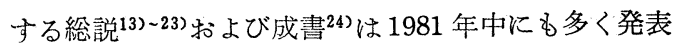
されている。

\section{1. 低温燃料電池}

かせいカリ水溶液, 固体高分子電解質, 超酸古るい はリン酸などを電解質とする電池が開発されている。

かせいカリ水溶液を電解質とする電池は $60 \sim 90^{\circ} \mathrm{C}$ で, 水素, アルコール25), あるいはアンモニア26)を燃 料として運転することが考兄ら祅ている。水素を燃料 とする電池は，アメリカでは主として宇宙開発用で, たとえばスペースシャトル用の然料電池は，石綿に35 \%かせいカリを含ませて電解液とし, ガス圧 4 気圧, $110^{\circ} \mathrm{C}$ で運転され，33 個の電池から成る $30 \mathrm{~V}$ の集合電 池 3 個は定格出力 $14 \mathrm{~kW}$, ピーク出力 $24 \mathrm{~kW}$ の電源となる 21)。また，水電解槽と燃料電池とを兼㱛をなえた再生 型燃料電池が $12 \mathrm{~kW}$ の規模でスペースシャトル用として 提案され，同様の $30 \mathrm{~kW}$ 電池が軍用に用いられている 27)。これらは太陽電池と結んで使用されるが，将来は $250 \mathrm{~kW}$ の電源として地上に执いて電力貯蔵用として用 いる構想もある。ヨーロッパでは自動車の動力源電池 として検討され，たとえば,ベルギーのElenco N.V. では, 石炭を一次燃料とする場合, アルカリ電解液水 素然料電池が最も高い効率を示すとしている ${ }^{28)}$ 。かが 国ではムーンライト計画のなかで, 富士電機グループ が担当し, 昭和 59 年度を目途として数㕍級の水素燃料 電池を開発する計画で29), ジルコニウム添加ラネーニ ッケル水素極 ${ }^{30)}$, 銀添加炭素触媒酸素電極 ${ }^{30331)}$ が開発 されている。アンモニアを燃料とする電池は,アンモニ アの熱分解水素を用いる方式で, 電気自動車用動力源 電池として考兄られ, この場合, $1 \sim 2.2 \mathrm{~kW} / \mathrm{m}^{2}$ の出力 密度で效率38〜40\%が兄られ，ピーク出力 $50 \mathrm{~kW}$ の電池 の価額は 2, 400 ドルで, $1.5 \mathrm{t}$ の乗用車が $14.1 \mathrm{~km} / \mathrm{kg}$. $\mathrm{NH}_{3}$ で高速道路を走行できるという26)。

固体高分子電解質を用いる燃料電池は, 陽イオンあ るいは陰イオン膜を用いて $80 \sim 150^{\circ} \mathrm{C} て ゙$ 運転される水 素酸素燃料電池である。前者では主として Nafion が 用いられ，軍用 ${ }^{32}$, 極寒地用 ${ }^{33}$ あるいは宇宙ステーシ ョン用として太陽電池と組み合わせた $500 \mathrm{~kW}$ まで再 生型電源として考兄られている34。後者では，たと党 ば, Permaplex 膜を電解質とし水素化 LaNis を水素 極とする電池がイタリアの Fiat で考兄られ，18kW， 
$90 \mathrm{Wh} / \mathrm{kg}$ の電池を Fiat 242 バンに搭載し, 時速 $50 \mathrm{~km}$ で250km走行できる可能性が示された ${ }^{35) 。 ~}$

超酸としては $\mathrm{CF}_{3} \mathrm{SO}_{3} \mathrm{H} 6$ モル水溶液が推奨され, これを炭化ケイ素，ガラス繊維などのマトリックスに

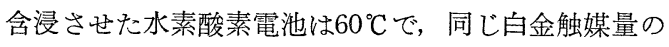
$180^{\circ}$ Cのリン酸燃料電池よりもすぐれた特性を示す ${ }^{-17)}$ 36)がこれは主として酸素電極特性が向上するためであ る3738)。さらに, $\mathrm{CF}_{2}\left(\mathrm{SO}_{3} \mathrm{H}\right)_{2}$ を電解液にすると200 ${ }^{\circ} \mathrm{C}$ まで運転温度を上昇させることができる ${ }^{39)}$ 。このと き触媒として白金よりも安価なWあるいはWCを水素 極用に，有機金属化合物を酸素電極用として使用でき $ろ^{17) 。}$

リン酸を電酸液とする燃料電池は最も開発度の高い 電池でリン酸を $\mathrm{SiC}$ マトリックスに含侵させて用い, アメリカでは軍用, 電気自動車用のほか冒頭でのべた OS/IES および電気事業用に検討されている。

アメリカの国防省ではアメリカ全体の約 $2 \%$ のエネ ルギーを消費しているので，その節約のために OS/ IES の40kW電池に関心を示し ${ }^{32}$, さらに, 野戦用に, Silent, Lightweight Electrical Energy Plant (SLEEP) として, ×タノール, No. 2 燃料油, ガソリ ンを改質して用いる1.5〜 5kW の移動電源電池を開発し ている40) 42)。電気自動車用としては, メタノール改 質然料を用いる電池が検討され，乗用車では，20kWの リン酸燃料電池と $4.8 \mathrm{kWh}$ の鉛蓄電池を搭載した $\mathrm{GM}$ $\mathrm{X}$ 想定して設計し，2人乗りで，最高時速 $110 \mathrm{~km}$ ， タノール 1 と 水 $0.45 \ell て ゙ ~ 12.3 \mathrm{~km}$ 走行できることが示 され，48人乗りの市バスでは, 定格出力 $130 \mathrm{~kW}, 370 \mathrm{~V}$ の燃料電池の久で, 時速 $93 \mathrm{~km}$ 最高時速 $105 \mathrm{~km}$ で走行で きるデータが党られている432 45)。アメリカの OS/IES 用としては Gas Research Institute(GRI), DOE お よびガス, 電気事業関保企業の援助によって, UTC, Westinghouse Electric Corp./Energy Research Corp. (WH/ERC) および Engelhard Industries (EI) で開発されつつあり, UTCでは40〜250kW, WH/ ERCでは120kW規模で考克，ともに，天然ガスを改質 して燃料とする方式である ${ }^{46) 。 た た ゙ し ， W H / E R C ~ は ~}$ 1981年末でこの開発を中止している47)。E I はメタノ ールを改質する方式で, 1981年現在 $5 \mathrm{~kW}$ のシステムを 作製しているが目標は50kW システムである ${ }^{48)}$ これれら 各社のリン酸燃料電池の最大の相違は電池の泠却方式 で, U T C は水冷, WH/ERC は空冷, E I は液冷 (Therminol 44) である。OS/IES では, 燃料電池 電力の添か, 排熱をヒートポンプ, 蓄熱装置によって 有効に利用し, HVAC (Heating, Ventilating and
Air-Conditioning) 設備をそな光た DEUS (Dual Energy Use System)として運転することが要点で, U T C の40kW出力電池では, 最高44kWの熱量が，大部 分が $71 \sim 82^{\circ} \mathrm{C}$ の温水，一部は $135^{\circ} \mathrm{C}$ までの熱水として 兄られる18)。このような, 電・熱併給システム (Cogeneration System) によって，電力の及では $40 \%$ の熱効率（L H V 規準）が80 85\%に向上する ${ }^{18)}$ 。わ が国でも事務所ビルを対象に検討され，充分適用でき ると評価されている499。

電気事業用としては，冒頭でのべたように交流出力 4. 5MWプラントが実証試験にはいららとしているが, New York プラントがナフサを改質して燃料とする のに対し，東京電カプラントは天然ガス改質ガスを用 い, 将来は石炭ガス化燃料を用いることを考党ている 3)。これらのプラントは $240 \mathrm{~kW}$ のリン酸燃料電池 20 個 から成るプラントで, Tennessee Valley Authority (TVA) では東京電力型の電池 1 個を購入して石炭が スでテストすることになっている200ここれらの電池は, 電極面積 $0.344 \mathrm{~m}^{2}$, ガス圧 3 気圧, $190^{\circ} \mathrm{C}$ で運転される が, 将来, 商用として考学られている11MWプラントで は, 電極面積 $0.929 \mathrm{~m}^{2}$ の電池 500 個から成る $675 \mathrm{~kW}$ のス ック18個の電池部本体構成 $(2,100 \mathrm{~V}) て ゙, 8$ 気圧, 207 ${ }^{\circ} \mathrm{C}$ で運転される予定である ${ }^{50051) 。 こ の た め, ~ V u l c a n ~}$ $\mathrm{X} \mathrm{C}-72 \mathrm{R}$ と称する電極炭素材の耐食性向上用に Regal $660 \mathrm{R}$ といら炭素材料 ${ }^{52}$, 岁る種の炭化物, ケイ化 物 ${ }^{53}$ が，白金触媒（酸素電極側 $0.75 \sim 0.5 \mathrm{mg} / \mathrm{cm}^{2}$, 燃 料電極側 $\left.0.75 \sim 0.25 \mathrm{mg} / \mathrm{cm}^{2}\right)$ の焼結防止用に $\mathrm{Pt} 3 \mathrm{~V}^{53}$ または Kocite といら特殊白金触媒 ${ }^{54) 55}$ )が提案され， 商用プラントでは，燃料から交流電力への変換効率 42 〜 46\%が光られるといら ${ }^{53) 。 こ の フ ゚ ラ ン ト は F ~ C ~ G-1 ~}$ (Fuel Cell Generator No.1) と名付けられ, 分散発 電所として使用しようとするすので，すでに $11 \mathrm{MW}$ ラントが 1 基 5,000 万ドルで 3 基売約済みで， メタン を含まない石炭ガスを燃料にする場合でも発電所建設 費はナフサ然料の場合の 4 〜 \% 高くなる程度である という 50556)。また，液体燃料の場合は断熱りホーマが 有効である る77といわれ，このようなF C G-1は11MW を 3 単位組み合わせ $33 \mathrm{MW}$ の間出力発電所として使 用することもできる ${ }^{5158) 。 ま た ， W H / E R C ~ て ゙ は ~ D I-~}$ GAS (Distributed Gas) と称する空冷式で直流出力 7. $5 \mathrm{MW}$ のプラントを1985 87 年までに建設する目的 で, WHの Advanced Energy Systems Division で376kWの電池モジュールの作製が始められておうう ${ }^{59)}$, これを20個用いた $7.5 \mathrm{MW}$ プラントは, 交流出力 7.2 MWで, メタノール, ナフサ, 天然ガス，石炭ガスな 
どを用いてプラント総効率40～46\%が期待され，原型 プラントでは, 1980年ベースで1, 940〜 1, 326 ドル/kW, 大量生産では775〜527ドル/kW の建設費, 7.04 ドル/ MBtu のメタノールを燃料とする場合の電力費73.5 ル $/ \mathrm{kWh}^{60)}$, 石炭を燃料としWHのガス化方式をとれ ば電力費49〜55ミル $/ \mathrm{kWh}^{61)}$ が考えられるといら。こ のプラントで, もし水冷式ならば90,000個のパイプ接 続点が必要であるがDIGAS 式では40個の接続点で足 り信頼性が増し14), さらに, 集電体にモールド黒鉛を 用いることができ，Mat-1 と称する49バールの圧力差 に耐えるマトリックスを用いることによりガス圧を 8 気圧にできるといら ${ }^{14) 62) 。 ~}$

わが国のムーンライト計画で当面考えられている交 流出力 $1 \mathrm{MW}$ リ酸燃料電池では, 発電効率 $40 \%$ 以上, 白金触媒 $6.5 \mathrm{mg} / \mathrm{W}$ 以下が目標とされ, 在来の火力発 電方式と同等以上の経済性が要求されている。

\section{2. 高温燃料電池}

溶融炭酸塩然料電池之固体電解質燃料電池とがあ る。

溶融炭酸塩燃料電池は $6500^{\circ} \mathrm{C}$ で運転され, $62: 38$ モ ル比の $\mathrm{Li}_{2} \mathrm{CO}_{3}, \mathrm{~K}_{2} \mathrm{CO}_{3}$ の混合塩を $60 \%$ (重量) にな るように $\mathrm{LiAlO}_{2}$ 粒子と混合したタイル状電解質, $\mathrm{Cr}$ あるいは $\mathrm{Co}$ を添加した $\mathrm{Ni}$ 然料極, $\mathrm{NiO}_{x}$ 空気極が

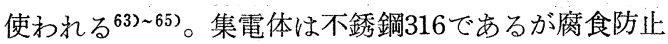
のためニッケル被覆66367), 高価な $\mathrm{LiAlO}_{2}$ の代わりに $\mathrm{SrTiO}_{3}, \mathrm{Ni}$ 燃料極の代わりにニッケル被覆セラミッ ク焼結体が提案されている67)。なお，53:47モル比の $\mathrm{Li}_{2} \mathrm{CO}_{3}$ と $\mathrm{Na}_{2} \mathrm{CO}_{3}$ との混合塩を電解質にすると, 蒸 気圧が低く熱膨脹係数も小さいため熱サイクル特性が 向上し ${ }^{68)}$ ，ガス圧を 5 〜 10 気圧にすることにより良好 な特性がえられる20)65)。また，燃料電極内で生成する 水をとのまま利用して，天然ガスを燃料電極室内で改 質して電池を運転する内部改質法69)を採用すればシス テム効率を15\%程度高めることができるという。

このよらな電池は，リン酸燃料電池を第 1 世代燃料 電池(First Generation Fuel Cell) とよぶのに対し 第 2 世代燃料電池 (Second Generation Fuel Cell) とよばれ，DOE，GRI によって DEUS 用として Cogeneration Technology Alternative Study (CTAS) のなかでとりあげられ，天然ガスを然料と する場合，燃料極で発生する水蒸気を，リホーマで利 用するか，高圧で熱水とするか，内部改質法で利用す るかの得失が論じられている20770)。現段階では $0.1 〜$ $0.15 \mathrm{~m}^{2}$ 面積の電極の 20 個の電池から成るスタックが試 験されている程度である20)71)が，1983年には1〜1. $5 \mathrm{~m}^{2}$
の面積の電極の 50～100 個の電池スタックを運転し, 1990年までに発電所プラントを実現させる予定である 71)。このプラントには, 石油, 天然ガス改質然料を用 いる中間負荷用分散発電所および石炭ガス化燃料を用 いるベース負荷用発電所プラントがある ${ }^{72)}$ 。前者の場 合, 交流出力 $4.5 \mathrm{MW}$ の規模で, 純建設費 561.4 ドル/ $\mathrm{kW}$ (然料電池本体 $39 \%$ ), 賦課金を加觉ると641ドル/ $\mathrm{kW}$ ，然料電池の交換費を考慮すると810.4ドル $/ \mathrm{kW}$ ，発 電効率 $44.8 \%$, 電力費 79.5 ミル $/ \mathrm{kWh}(4.74$ ドル/MB $\mathrm{tu}$ 燃料の燃料費 $47 \%$ ）の試算が報告され，後者の場合， Texaco の酸素法石炭ガス化装置を用い，排熱でスチ 一ム発電する 675MW の発電所が評洒され純建設費 725.6 ドル $/ \mathrm{kW}$ ，諸経費込みで 845.7 ドル $/ \mathrm{kW}$ ，電池交換 費を加えると 1014 ドル $/ \mathrm{kW} ，$ 発電総効率 $51.2 \% ， 1.43$ ドル/MBtu の石炭を使用すれば, 初年度の電力費46.7 ミル $/ \mathrm{kWh}$ (然料費 $20.6 \%$ ) と試算されている ${ }^{73}$ 。ま た, NASA の Energy Conversion Alternatives Study (ECAS) のなかで評価された1,430MWの石炭 然料電池発電所では, Texaco の酸素法石炭ガス化装 置を用いて総効率 $47.9 \%, 1$ ドル/MBtu の石炭の值上 がりを年率 $6.2 \%$ とすると 30 年間平均の電力費 45.8 ミ

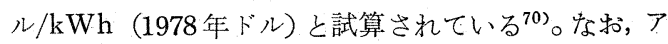
メリカでは，石炭をガス化せず直接燃料とする溶融炭 酸塩燃料電池も研究されている ${ }^{74)}$ 。溶融炭酸塩燃料電 池に関するわが国のムーンライト計画の目標は，電極 面積 $0.2 \mathrm{~m}^{2}$ の $210 \mathrm{~kW}$ の電池について $45 \%$ 以上の発電効 率をらることであり，昭和 62 年度以降の第II 期におい て $1 \mathrm{MW}$ 級の実証プラントの建設試験を予定している 29)。

固体酸化物電解質燃料電池は，第 3 世代 燃料 電 池 (Third Generation Fuel Cell) とよばれ将来を期 待されているが開発度は低い。現在, 試験電池を構成 して研究しているのは，アメリカのWHとわが国の工 業技術院電子技術総合研究所（ET L) のみである。 $\mathrm{WH}$ では， $\mathrm{CaO}$ で安定化したジルコニア管上へ， $\mathrm{Ni}$ ジルコニアサーメット燃料極, $\left(\mathrm{ZrO}_{2}\right) 0.9\left(\mathrm{Y}_{2} \mathrm{O}_{3}\right) 0.1$ 電解 質，すずを添加した $\mathrm{In}_{2} \mathrm{O}_{3}$ 空気極の順に，各20〜 $50 \mu \mathrm{m}$ の薄膜で析出させて電池を形成し，インタコネクタと して $\mathrm{LaCr} 0.9 \mathrm{Mg} 0.1 \mathrm{O}_{3}$ を用い.75)76)，20個の電池を直列 に結び, $1,000{ }^{\circ} \mathrm{C}$ で水素と C O との混合ガスで運転し, このデータに基づいて, 直流出力 $220 \mathrm{MW}$ のプラントを 11. $7 \mathrm{kBtu} / \mathrm{m}^{3}$ の石炭ガスで運転する場合を想定して 試算し，(1)ボトミングサイクル発電で92.5MWの交流 電力が えられる，(2) ボトミングサイクル 発電で 35.3 $\mathrm{MW}$ 交流電力と $230^{\circ} \mathrm{C}, 10.5 \mathrm{~kg} / \mathrm{cm}^{2}$ の水蒸気 $273 \mathrm{t} / \mathrm{h}$ 
(731MBtu/h) がえられる，(3) $240^{\circ} \mathrm{C}, 10.5 \mathrm{~kg} / \mathrm{cm}^{2}$ の水 蒸気が 1 時間あたり $342 \mathrm{t}$ 兄られるとした。さらに, 各 場合について，1990年におけるプラント建設費を推定 し, 5 年毎に電池を交換するとして, (1)532ドル/ $\mathrm{kW},(2)$ 559 ドル $/ \mathrm{kW} ，(3) 545$ ドル $/ \mathrm{kW}(1980$ 年ドル)の值をえ, 電 力費も推定している77778)。なお, 実際には電池部分の冷 却のため多量の空気を必要とするため，WHでは1981 年後半から, 電極の配置を逆にし, $\mathrm{In}_{2} \mathrm{O}_{3}$ が高価なの で，空気極を， $\mathrm{Ca}$ を添加した $\mathrm{LaMnO}_{3}$ に変光るよ らにすべての仕様を変更している79)。WHはこの電池 の開発に関して1981～84年にD O E の補助金と自己資 金の合計として7Mドルの開発費を予定している ${ }^{80) 。 ~}$ E T L では，空気極としてCa を添加した $\mathrm{LaCoO}_{3}$ を 用いWH と似た手法で12個の直列電池群をえ，これを 9 個用い, $1,000^{\circ} \mathrm{C}$ で開路電圧 $92.5 \mathrm{~V}$, 作動電圧 36.6 Vで最大出力 $110 \mathrm{Wをえている(1)} \mathrm{84)。なお，250MW}$ の発電所について計算し，燃料を 30 円 $/ \mathrm{Nm}^{3}$ とすると 発電原価は24.85円になるとい585)。ムーンライト計 画の目標は, 発電効率 $50 \%$ である29\%。

\section{3. あとがき}

アメリカの燃料電池プラント開発は, 電気事業外の 施設が電・熱併給方式で発電した電力を, 電気事業の 企業に対して買い取ることを義務ずけた PURPA と よばれている法令 (Public Utility Regulatory Policies Act of 1978) ${ }^{86887)}$ で援護, 推進されている面 がありわが国においてもこの種の法的処置も必要で あろう。しかし，アメリカのDOEの1982会計年度の 燃料電池関係予算の配分がリン酸燃料電池 $21 \mathrm{M} ト$ ド,

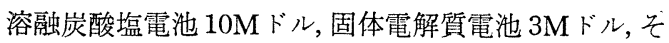
の他 $0.5 \mathrm{M}$ ドル88) であるのに対しムーンライトの燃 料電池開発 6 年間の予算の $5 ち 68 \%$ に相当する 75 億円 がリン酸燃料電池開発に支出の予定である ${ }^{29}$ ことは, 額の多少を別にすれば両者が似た比率の配分であるこ とを示していて興味がある。

\section{文献}

1）記事，日刊工業新聞，2 月23日（1982）

2) Glasser, K. F., Abst. Natl. Fuel Cell Seminar, p. 5, Norfolk, Virginia

3) Kobayashi, M., ibid., p. 9

4) Landgrebe, A. R., et al., Modern Power System, May, p. 42

5) Piaseck, R., Abst. Natl. Fuel Cell Seminar, p. 22, Norfolk, Virginia

6）小倉義弘, 電気新聞, 8 月 17 日，21日

7）記事，日刊工業新聞，3月 3 日 (1982)

8）小林喬, 他, 電気学会誌, 102, 191 (1982)

9）酒井貴史，他，電池討論会， 22，79，京都
10）記事，電気新聞，8月28日

11) Rigney, D. M., Abst. Natl. Fuel Cell Seminar, p. 1, Norfolk, Virginia

12) Zlotnick, M., 私信 (Nov.,)

13) Tilak, B. V., et al., Comprehensive Treatise of Electrochemistry, Vol. 3 Eds. Bockris, J. O'M., et al., Plenum Press, New York, p.39

14) Maru, H.C., et al., Intnatl. Power Generation, Feb., p. 73

15) Abens, S., ibid., April, p. 10

16) Ragsdale, H.E., et al., Oil Gas J., 79, (45), 226,230

17) Landgrebe, A. R., et al., Proc. IECEC, 16, (Vol. 1), 738

18) Sperberg, R.T., et al., ibid., 708

19) Breelle, Y., et al., Rev. Inst. Fr. Pet., 36, (4), 485

20) Fickett, A. P., EPRI, EM-1730, RP 114 March

21）高橋武彦，電池技術，電池技術委員会，大阪， p.118

22）小沢丈夫，エネルギー变換技術，エネルギー変換 懇話会, 東京, p. 95

23）城上 保, 電子通信誌， 64，（2），173

24）小沢丈夫, 他, 燃料電池とその応用 (オーム社) 東京

25) Vasudev, G., et al., Trans. SAEST, 16, (2), 89

26) Ross, Jr., P. N., Proc. IECEC, 16, (Vol.1), 726

27) Schubert, F. H., et al., ibid., 16, (Vol.1), 61

28) Van den Broeck, H., Energy Storage, Ed. Silverman, J., Pergamon Press, New York (1980), p. 230

29）福田隆三，新電気， 36，(1)，77，(2)，45（1982）

30）昭和 55 年度サンシャイン計画成果報告書概要集 (水素エネルギー), 日本産業技術振興協会, 東京 p. 98

31）小関和雄, 他, 電池討論会要旨集, 22, 67, (京都)

32) Barthelemy, R., Abst. Natl. Fuel Cell Seminar, p. 35, Norfolk, Virginia

33) Criddle, E. E., et al., Proc. Power Sources Conf., 29, 4 (1980) (出版は1981)

34) Erickson, A.C., et al., Proc. IECEC, 16, (Vol. 1), 67

35) Folonari, C., et al., J. Less-Common Metals, 74, 371

36) Adams, A. A., et al., Proc. Power Sources Conf., 29, 6 (1980) (出版は1981)

37) Srinivasan, S., et al., Abst. U.S.DOE Battery Electrochem. Contractors' Conf. p. 412, Washington D. C.

38) O'Grady, W.E., et al., Abst. Natl. Fuel Cell Seminar, p. 84, Norfolk, Virginia

39) Walsh, M. A., et al., ibid., p. 86

40) Abens, S. G., et al., ibid., p. 120 
41) Joebstl, J.A., et al., ibid., p. 81

42) Summers, W. A., ibid., p. 119

43) Lynn, D, K., et al., Proc. IECEC, 16, (Vol. 1), 722

44) Huff, J. R., et al., Abst. Natl. Fuel Cell Seminar, p. 37, Norfolk, Virginia

45) Huff, J. R., Abst. U. S. DOE Battery Electrochem. Contractors' Conf., p. 399, Washington D.C.

46) Buggy, J. J., et al., Abst. Natl. Fuel Cell Seminar, p. 56, Norfolk, Virginia

47) Baker, B. S., 談話 (June)

48) Johnson, G. K., et al., Abst. Natl. Fuel Cell Seminar, p. 43, Norfolk, Virginia ; DOE/ NASA/0241-2, NASA CR-165455 (Aug.)

49）上之園 博, 他, 電気学会研究資料, E D-81-41 $\sim 51$, E S C-81-17 27, p. 63

50) Jackson, S. B., et al., Proc. IECEC, 16, (Vol. 1), 713

51) Rigney, D. M., EPRI, EM-2123, RP 1777-1, Nov.

52) McBreen, J., et al., J. Appl. Electrochem., 11, 787

53) Appleby, A. J., Abst. Natl. Fuel Cell Seminar, p. 46, Norfolk, Virginia

54) Welsh, L. B., et al., US Army. Contract No. DAAK 70-79-C-0173, UOP Inc., Illinois

55) Appleby, A. J., EPRI, EM-1711, RP 1200-3, Feb.

56) Jackson, S. B., Abst. Natl. Fuel Cell Seminar, p. 52, Norfolk, Virginia

57) Gillis, E. A., EPRI, EM-1701, RP 1041-4, Feb.

58) Cohen, R., Abst. Natl. Fuel Cell Seminar, p. 48, Norfolk, Virginia

59) Farbman, G., 談話 (June)

60) Gillis, E. A., EPRI, EM-1936, RP 1041-7, Feb., July

61) Dighe, S. V., et al., Proc. IECEC, 16, (Vol. 2), 1059

62) Buggy, J. J., et al., Abst. Natl. Fuel Cell Seminar, p. 41, Norfolk, Virginia

63) Selman, J. R., Prog. B. \& S., 4, 284 (1982)

64) Blurton, K. F., et al., Power Sources, No. 8, Ed. Thompson, J., Academic Press, London, p. 211

65) Ong, E. T., et al., Abst. Natl. Fuel Cell Seminar, p. 77, Norfolk, Virginia

66) Browall, K.W., et al., ibid., p. 137

67) Dawes, M. H., et al., Proc. IECEC, 16, (Vol. 1), 703

68) Li, C. T., et al., Abst. Natl. Fuel Cell Seminar, p. 140, Norfolk, Virginia

69) Patel, P.S., et al., ibid., p. 106
70) Healy, H.C., et al., ibid., p. 62

71) Krumpelt, M., et al., Proc. IECEC, 16, (Vol. 1), 699

72) Peterson, J. R., et al., Abst. Natl. Fuel Cell Seminar, p. 67, Norfolk, Virginia

73) Mehta, B. R., EPRI, EM-1670, RP 1085-1, Jan.

74) Weaver, R. D., et al., Proc. IECEC, 16, (Vol. 1), 717

75) Zymboly, G. E., Abst. Natl. Fuel Cell Seminar, p. 74, Norfolk, Virginia

76) Isenberg, A. O., Solid State Ionics, 3/4, 431

77) Federmann, E. F., Abst. Natl. Fuel Cell Seminar, p. 99, Norfolk, Virginia

78) Federmann, E. F., et al., DOE Contract No. DE-AC-0379 ET 11305, Westinghouse R \& D Center, Pennsylvania, Feb.

79) Isenberg, A. O., et al., 談話 (June)

80) Brown, J. T., 談話 (June)

81) Ohno, Y., et al., Solid State Ionics, 3/4, 439

82) Negishi, K., et al., ibid., 3/4, 443

83）サンシャイン計画研究開発結果報告書「高温固体 電解質燃料電池の研究」電子技術総合研 ( 3 月)

84）永田進, 他, 高温学会誌, 7, 217

85）佐藤弘之, 固体電解質材料調查報告書, 日本電子 工業振興協会, p. 122

86) Larson, E.S., Abst. Natl. Fuel Cell Seminar, p. 20, Norfolk, Virginia

87) Nimmons, J. T., et al., ibid., p. 30

88) Zlotnick, M., 私信 (Jan., 1982)

\section{4 太陽エネルギー利用の動向}

\section{1. まえがき}

新エネルギーの開発が進められる中で, 資源エネル ギ一庁による各都道府県の口ーカルエネルギー資源の 賦存量調查は第 2 年目の段階に入り, 55 年度に未調査 の府県について太陽ェネルギー, 風力, 地熱, 中小水 力などの資源賦存量の調查が行われている。太陽エネ ルギーの開発も㹉々実用化に拍車がかけられて各種の プロジェクトが進みつつあるのが昭和56年の現状であ ろら。

\section{2. 太陽冷暖房・給湯}

太陽冷暖房・給湯システムの研究開発と並んで普及 促進のための政策が進められているが，昭和56年でど のような成果が得られたかをると見ると，通産省 生活産業局住宅産業課により推進されている地方公共 建物のソーラーシステム化汶対する補助金交付と, 個 人住宅や事業所ビルに対する低利融資が進みつつあ 


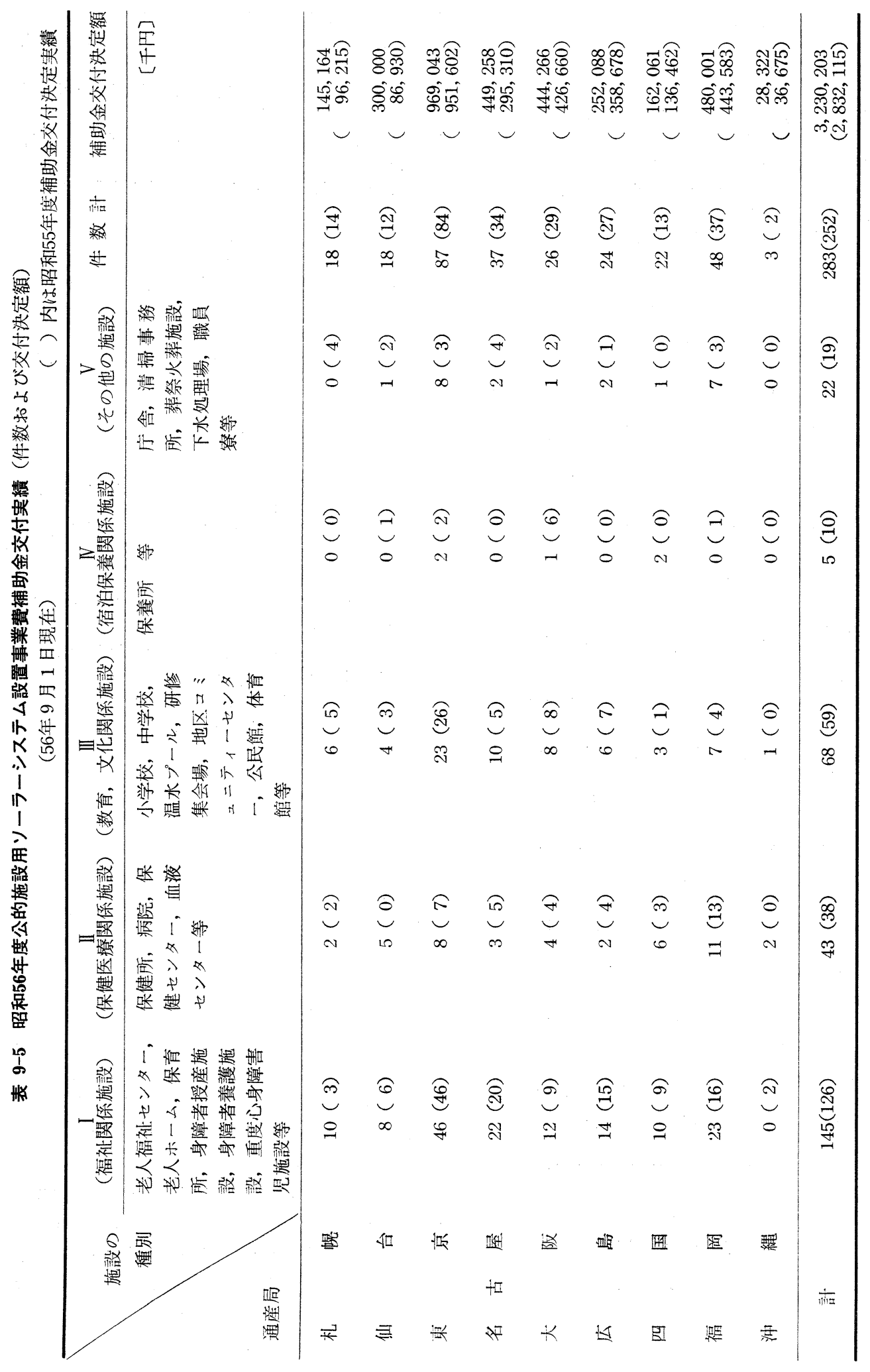




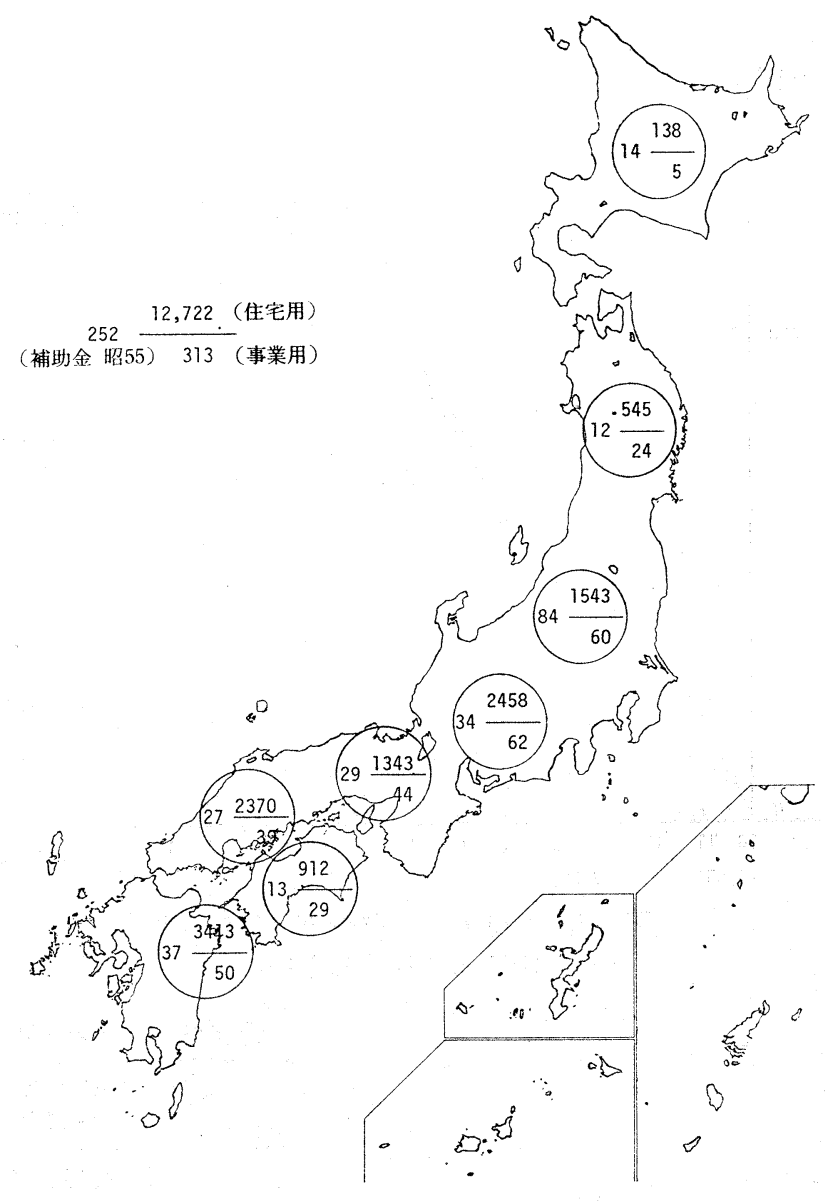

図 9-4 ソーラーシステム融資実績

（昭和56年12月末日現在）

る。

補助金交付件数の明細は表 9-5 に示す通りで件数は 年間約 250 件数を超え， $50 \%$ 補助が行われている。予 算規模は昭和 55 年度の 30 億より 36 億に増額されて抒り 事業規模としては72億となった。また個人住宅および 事業所ビルのソーラーシステム化への低利融資枠は 100 億より110億に増額されて着実に伸びている。図9-4 に各通産局を中心 にした昭和 55 年度の公共建物に対 する補助金交付件数と，また分子並びに分母に低利融 資の個人住宅拉よび事業所ビルの件数を示す。比較的 日射量の豊富な中部以西に多いことが示されている。

さらに上記融資件数の推移を見ると図 9-5 亿揭げる ように昭和 56 年中には上昇線を示して扮り，この傾向 は今後も続くものと思われる。これらの融資件数や補 助金交付件数などをる含めた昭和 56 年中に建設された
ソーラーシステムの総件数は表 9-6 と示すような伸び を示している。一方, 太陽熱温水器の需要は住宅事情 の不況の影響もあって伸び悩み，昭和55年より少なく 約56万台となっているが，依然として自然循環方式が 主流を占め, 汲み置き式温水器より設置数が多い。

以上の上うに太陽冷暖房・給湯システムの普及促進 化に行政面や産業界からの努力が続けられているが， 一方研究開発 ${ }^{11}$ の分野では工業技術院名古屋工業技術 試験所において太陽集熱器材料の評価・試験法や集熱 器の試験法, カプセル化による潜熱蓄熱, 吸着冷房に関 する基礎研究がサンシャイン計画で進められている。 これと並んで実証化研究では新ェネルギー総合開発機 構に委託して産業用ソーラーシステムの開発が進み, 日立製作所による尾張一宫市の日本毛織侏の染色プラ ント工程のソーラー化，川崎重工侏の宮崎県の農業用 


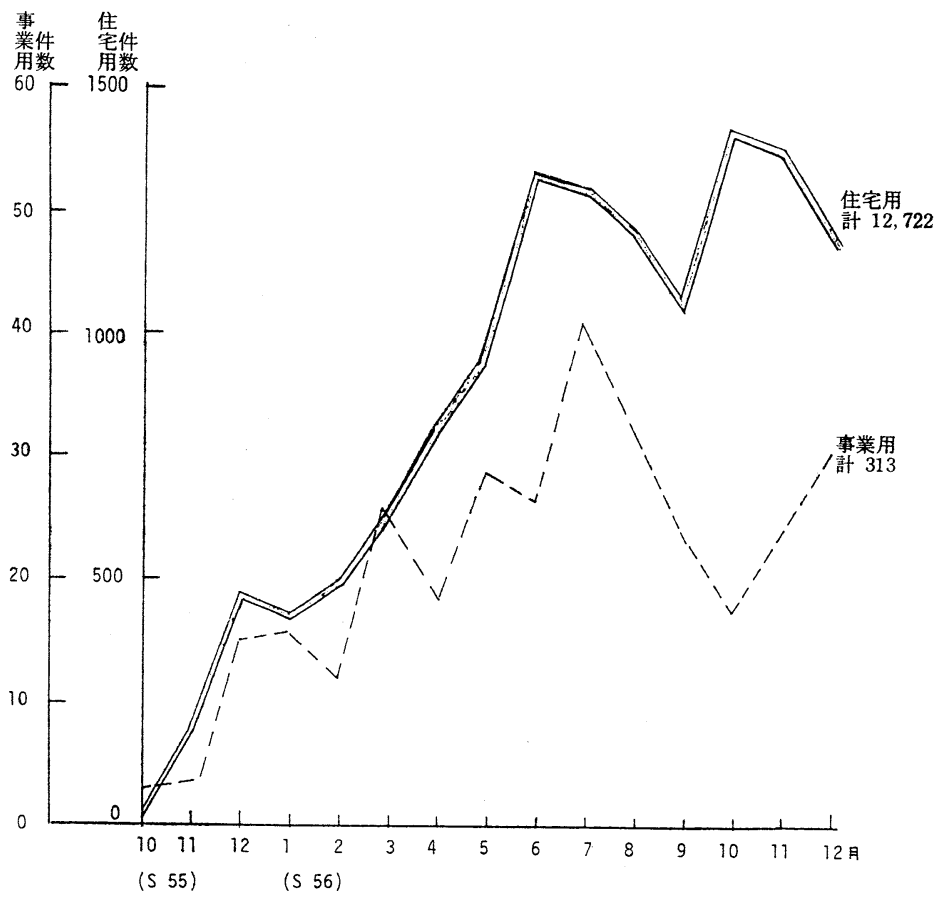

図 9-5 月別ソーラーシステム融資件数

（昭和56年12月末現在）

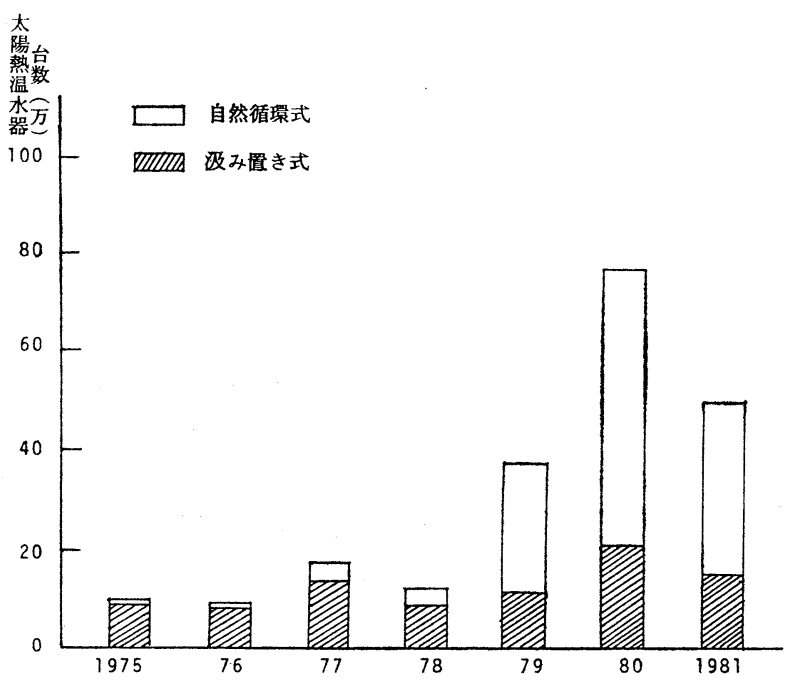

図 9-6 太陽熱温水器普及状況

（昭和56年12月末現在）

のもみや茶の備蓄用定温倉庫のソーラー化システム設 計が行われている。このよらな背景をもとに10月には 日本太陽エネルギー学会主催による産業用ソーラーシ ステムのセミナーが開催された。るた長期蓄熱では大 林組が夷証化研究として土中蓄熱技術を, 三洋電機秼
表 9-6 ソーラーシステム販売・施行件数

\begin{tabular}{|c|c|c|c|c|}
\hline システム & $\begin{array}{c}\text { 昭和 } 50 \text { 年 } \\
\sim 54 \text { 年 }\end{array}$ & 55 & 56 & 小計 \\
\hline 湯 & 4,121 & 25,054 & 31,829 & 61,004 \\
\hline 暖 房・給 湯 & 371 & 336 & 133 & 840 \\
\hline 冷暖房 - 給湯 & 125 & 116 & 87 & 328 \\
\hline 産業用その他 & 31 & 24 & 30 & 85 \\
\hline 合計 & 4,648 & 25,530 & 32,079 & 62,257 \\
\hline
\end{tabular}

が金属水素化物による化学反応蓄熱を受話して 開発を進めている。

また文部省ではエネルギー特別研究のための 研究補助金制度を発足させ，自然エネルギーの 研究の枠の中で, 地熱と並んで19件の太陽エネ ルギーの利用の研究を推進しつつある。この中 ではパッシブソーラーシステムの研究が多く, 長期蓄熱, 選択膜材料, システムの最適制御などにつ いて各大学で研究が進められている。

太陽集熱器の国家検定を目指して通産省生活産業局 住宅産業課より機械電子榆査検定協会へ委託されたり ーラーシミュレータの概念設計も症ぼまとまり浜松に 


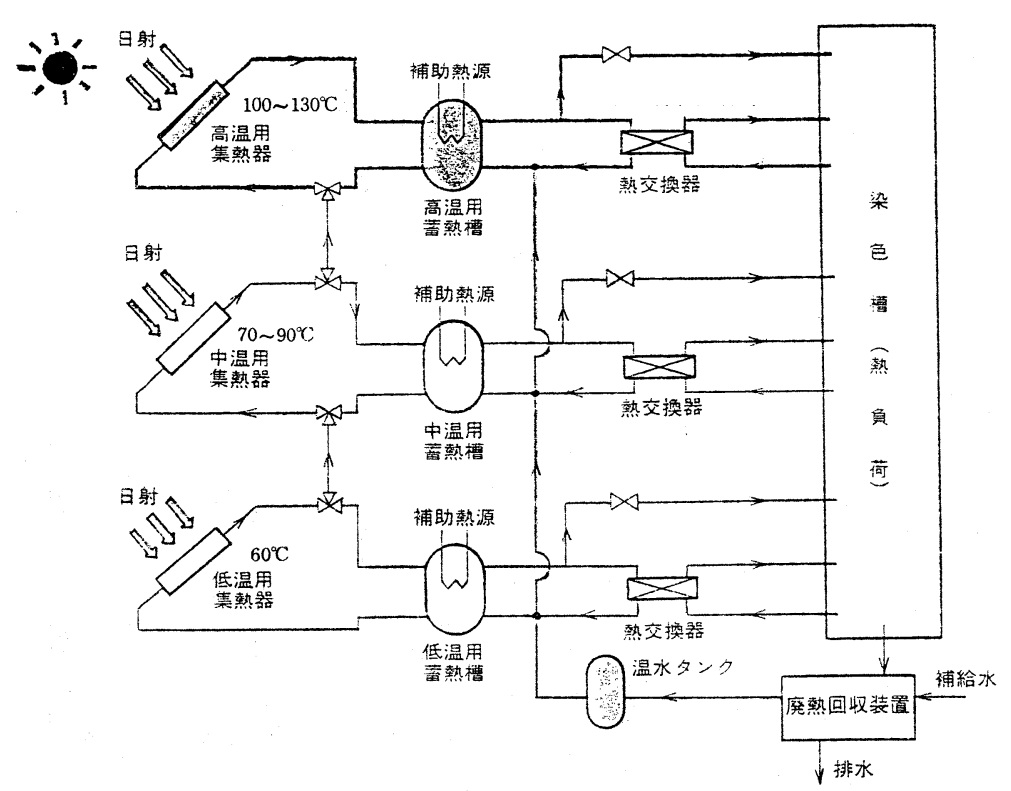

染色プロセス用エネルギーシステム

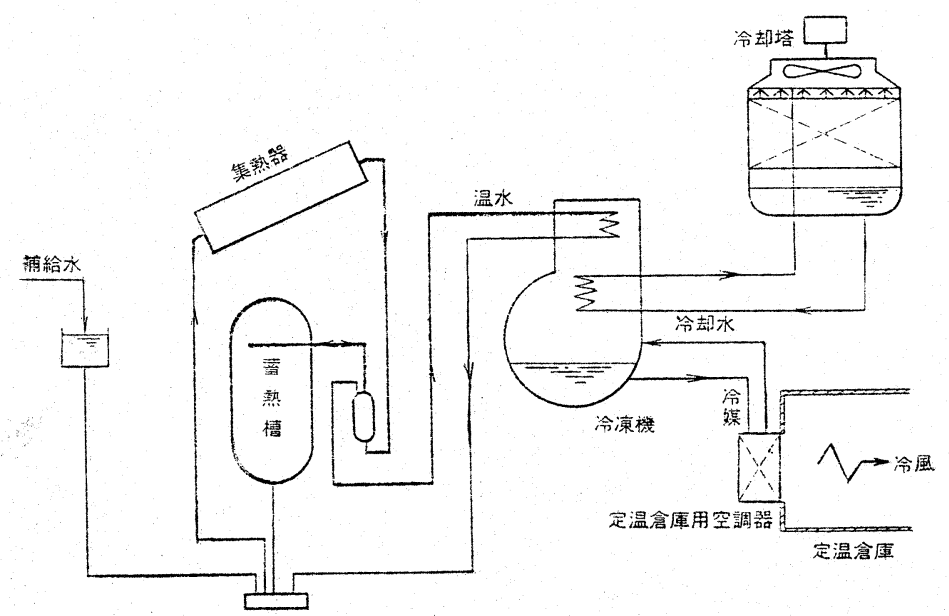

定温倉庫システム

図 9-7 産業用ソーラーシステム 2 方式のシステムフロー図

建設の予定で作業が進められつつある。

機械システム振興協会が香川県直島町の高見島へ建 設中の太陽熱利用海水淡水化プラントは56年 8 月に完 成して試運転に入った。これは真空断熱管状高性能集 熱器と多段フラッシュ蒸発機および電気透析法と平板 型集熱器システムの 2 方式によるハイブリッドシステ ムで日産 $20 \mathrm{t}$, 集熱器面積当り $5 \sim 8 \ell / \mathrm{m}^{2}$ の造水能力を 持つもので今後続けて運転研究が実施される。

太陽冷暖房・給湯技術は太陽エネルギーの利用開発 の中でも最も早く開花した分野であり，実用化に向け
て積極的な対策が取られているが，今後の問題点とし ては, 耐久性・信頼性の向上と確立並びにその試験法 の確立が挙げられ，技術的には凍結防止，空焚き防止 や雪害対策の確立と経済性の追究が挙げられよう。

\section{2. 太陽熱発電}

太陽熱発電の分野で昭和56年は特記すべき年であっ たといえる。すなわち各国で建設中であった大型太陽 熱発電プラントが56年後半に続々と完成し, 運転試験 の段階に入ったからである。わが国の香川県尾町の 塩田跡に建設中であったタワ一集光方式および平面・ 

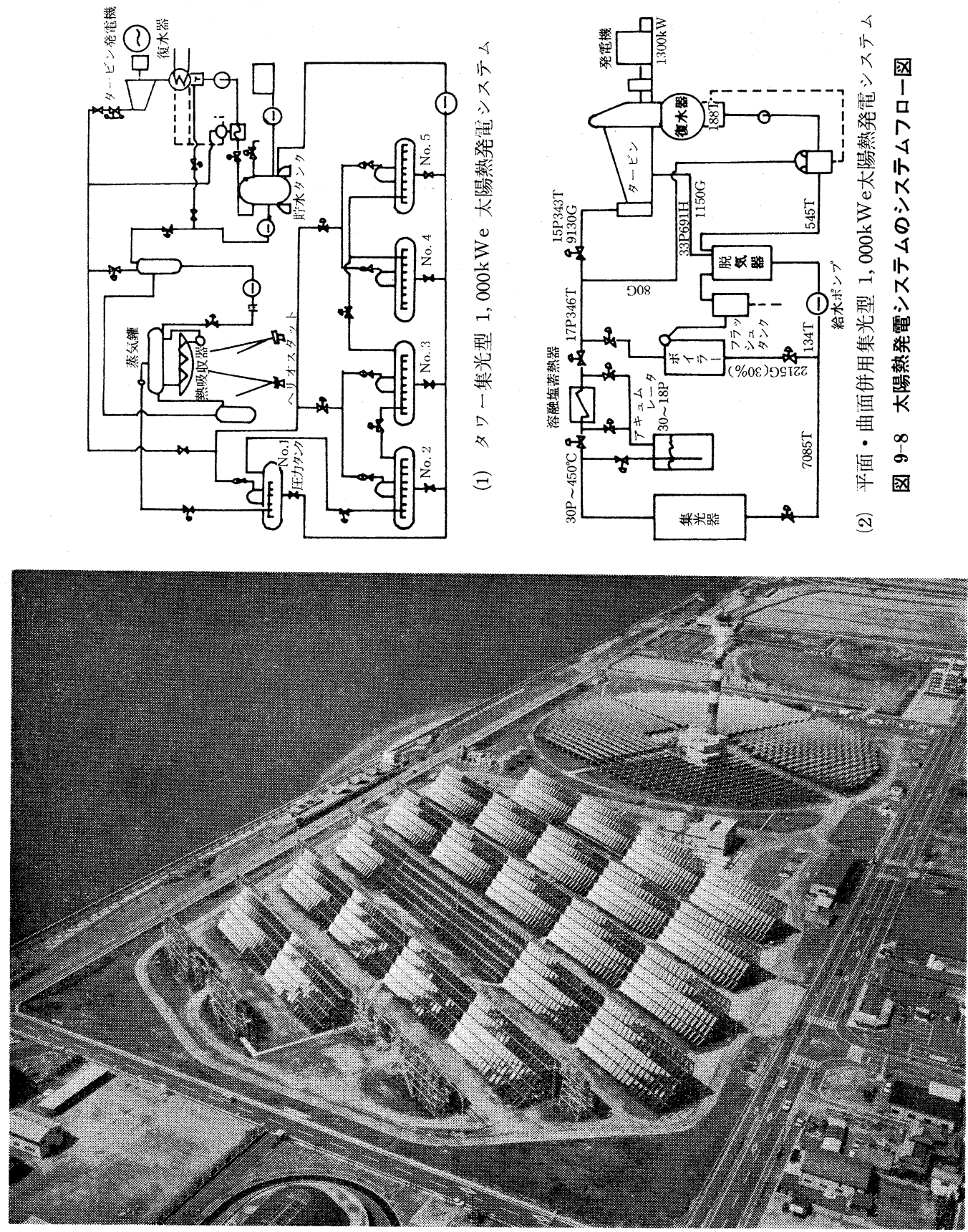

(手前が平面・曲面併用型システム，後方のタワーを含む円陣型が

タワー集光方式でそれぞれ $1,000 \mathrm{kWe}$ の発電能力を有する。

図 9-9 香川県仁尾町に設置された $1,000 \mathrm{kWe}$ 太陽熱発電プラント 2 基の全貌

曲面集光型の 2 方式各 $1,000 \mathrm{kWe}$ の建設が世界に先駆 けて56年 8 月末に完成した。それらのシステムフロー および全貌をそれぞれ図 9-8および 9-9 に示す。今後
2 年間の運転試験を行ってシステム特性の評価・解析 を進めると共に, 各要素機器の開発も進められる。ま た太陽熱発電技術の経済性の追究と併行して熱電気併 
給システムのシステム解析とフィージビリティ スタディが電子技術総合研究所を中心に行われ ている。

\section{3. 太陽光発電}

サンシャイン計画をスタートした昭和 49 年当 時より太陽電池素子の $1 / 100$ コストダウンが太 陽光発電の大きな命題であったが，当時ピーク ワット当り 3 万円であったものが現在約 4,000 円まで下がってきた。現在この分野では基礎研 究と共に実用化技術開発が並行して行われてい る。

基礎研究ともては II -VI 族化合物半導体とし て CdS-CdTe 素子の開発之製造工程の大幅短 縮の期待できる $\mathrm{SnO}_{2}$ 太陽電池の研究開発が進 められている。これと並んでアモルファス太陽 電池の研究開発では, 多層構造や集積型等計 7 社に研究委託が行われ，またアモルファスシリ コンに関する物性研究が 7 大学で進められてい る。

垁用化技術開発の分野では，原材料の低コス トシリコンの精製, 太陽電池パネルの大量, 連 続製作技術の開発, 光熱ハイブリッド型太陽電 池システムの開発, 集光型光発電システムの開 発, 太陽光発電システムの周辺要素機器の開発, 太陽 電池パネル評価用のソーラーシミュレータの製作など の研究委託と並んで，太陽光発電デモンストレーショ ン計画がスタートした。このデモンストレーションに は，3kWの個人住宅用システム (葉山)，20kWの集合住 宅用システム(天理), $200 \mathrm{~kW}$ 学校用システム(筑波), および100kWの工場用システム(浜松) の 4 種類が，ま た集中配置型の $1,000 \mathrm{~kW}$ システムが四国西条市，200kW の分散配置型システムが千葉市に建設されることにな った。

\section{4. 国際協力と海外專情}

\section{1 国際協力}

国際エネルギー機関（I E A ）による多国間協力の 分野では，太陽冷暖房・給湯プログラムの中で，わが 国が議長を勤める $\mathrm{T}_{\text {ASK II }}$ 太陽冷暖房コンポーネント の開発に関する専門家会議が 4 月ウイーンで開催さ れ，第 1 次 3 ケ年計画が終了乙てその活動の延長が承 認され，1984年 6 月まで第 2 期 3 ケ年計画が進められ ることになった。この間に出版された報告書は太陽冷 暖房コンポーネントに関する各国のプロジェクトに関 するもの 2) と各国の太陽冷暖房開発計画 ${ }^{32}$ に関するも のである。10月には再びロンドンに拉いて專門家会議

\section{表 9-7 IEA 太陽冷暖房プログラム加盟国の活動状況}

\begin{tabular}{lc} 
Country & Signed I.A. \\
\cline { 2 - 2 } Australia & $x$ \\
Austria & $x$ \\
Belgium & $x$ \\
Canada & $x$ \\
Denmark & $x$ \\
Germany & $x$ \\
Greece & $x$ \\
Italy & $x$ \\
Japan & $x$ \\
Netherlands & $x$ \\
Neiv Zealand & $x$ \\
Norway & $x$ \\
Spain & $x$ \\
Sweden & $x$ \\
Switzerland & $x$ \\
UK & $x$ \\
USA & $x$ \\
CEC & $x$ \\
O & TOTAL \\
* 議長国 & \\
参加希望 & $x$ \\
\end{tabular}

(1981. 10月現在)

が開催されている。

また IEA T $T_{A S K} V$ では三洋電機枚方ソーラーハウ スを利用して真空管型集熱器によるシステムの運転計 測を行い，各種真空管型集熱器の性能比較研究に参加 した。

また 2 ケ国間協力では日豪技術協力協定が発足して 高級平板型集熱器の試験法の共同研究が名古屋工業技 術試験所之CSIRO の間に開始され，オイルループに よる真空管型集熱器の $200^{\circ} \mathrm{C}$ に和ける運転・評価の研 究が開始された。また太陽光発電システムの情報交换 も行われている。

8 月には英国 Brighton の Brighton Center に和 いて国際太陽エネルギー協会 (ISES) 主催による国際 太陽エネルギー会議 Solar World Forum が開催さ れ，76ケ国約 1,600 人以上の参加者があり，発表論文 は550を越えるマンモス会議となった。代替エネルキ 一資源の研究開発に先進国並びに開発途上国共に非常 に強い関心を示し，新しい太陽エネルギー産業が誕生 しつつ数る時機でもあるので非常に熱気のこもった会 議となり盛況であった。わが国よりの提出論文は19篇 であうた。

この会議のセッションは次の通りである。 
8 月24日 パッシブ冷暖房

バイオマス

日射観測とデータ

8 月25日 アクティブ冷暖房

社会経済, 立法, 環境, 普及, 教育問題 国際およびナショナルプロジェクト

8 月26日 産業用ソーラープロセスヒート

光化学

8 月27日 光 $\cdot$ 熱発電

農業利用

シミュレーションとモデリング

な拈その他にも次の 9 つのトピックスについてワー クショップが会議中に開かれた。

嫌気性醱酵, パッシブシステム, 各国の太陽冷暖房 ナショナルプロジェクト, 教育問題, 灌溉用水ポンピ ソグ，ソーラーポンド，英国風力エネルギーコロキウ ム，日射データ，ユネスコの開発途上国ワークショッ プである。

\section{2 海外事情4)}

太陽冷暖房・給湯システムの研究開発と普及状況に ついては, 米国とわが国が他の先進各国に比較して進 捗しているといえる。米国ではレーガン政権の核重視 政策により太陽冷暖房関連予算は大幅なカットを受け ているが，1980年の太陽集熱器のメーカー数は364社, 低温集熱器の出荷高は 119 万 $\mathrm{m}^{2}$, 中高温集熱器は 75 万 $\mathrm{m}^{2}$, 計 194 万 $\mathrm{m}^{2}$ となっている。1970 年代半ば以降進め てきた14,000戸以上のデモンストレーション住宅プロ グラムはほぼ終了したとして今後最高 1 万ドルまでの ソーラーシステムへの投資に対する $40 \%$ の税控除体制 へ移行した。その他の国々ではまだデモンストレーシ ョンプログラムおよび研究開発が中心である。

太陽熱発電の分野では，米国が Albuquerque の Sandia 国立研究所ですでに稼働している $3 \mathrm{MWt}$ に 併せて13件の概念設計が行われ，この中 7 件は電力用, 他の 6 件は産業用熱源である。また California の Barstow にタワー集光方式の 10MWe の Solar One が1981年末に建設を完了した。

また IEA では独の DFVLR が議長を担当してス ペインのアルメニアではタワー集光方式 $500 \mathrm{kWe}$, 分 散集光方式 $500 \mathrm{kWe}$ 計 $1,000 \mathrm{kWe}$ の太陽熱発電プラ ントを昭和 56 年秋に完成させ, E C もイタリアのシシ リー易で $1,000 \mathrm{kWe}$ のタワー方式 Eurelios が秋に完 成して稼働を始めた。一方フランスでは Thémis プ ロジェクトの中で Pyrénée-Orientales の Targasonne で $2.5 \mathrm{MW}$ 級の発電所を COMES とフランス電
力公社 E D F が中心になって10月に完成するなど各国 で $1 \mathrm{MW}$ 級以上の太陽熱発電所が昭和56年の年内に完 成しており今後の運転試験と性能評価の結果の発表が 俟たれる。

太陽電池の分野ではやはり米国が群を抜いて，1980 年の光電池モジュールの出荷量は $4,240 \mathrm{kWp}$ で，この 中, 輸出分が $42 \%$, 産業用 $37 \%$ その他となっている。

また独の太陽エネルギー技術の特徵は輸出用産業と しての観点が中心と見られよう。

\section{5. まとめ}

石油事情がやや緩んできた情況下で新エネルギー開 発も今後その経済性追究の縓しい矢面に立つことにな ると思われる。長期的に見た場合には化石燃料の有限 性は依然としてわれわれの前に立ちはだかっており, 今後太陽エネルギー技術の分野でも，耐久性や信頼性 の向上と共に経済性の追究が重要な課題となると考え られる。

実用化の進む一方で，応用分野の非常に広範な太陽 エネルギー技術の基礎研究もゆるがせにできない分野 であり，かつまた今後開発途上国への技術開発援助や 技術移転も真剣に取り組まねばならない課題である。

\section{文献}

1）名工試研究発表会予稿集一太陽エネルギー部門 第30回 昭和56年 6 月; 第31回 昭和56年12月

2) Noguchi, T., "Survey of Solar Energy R \& D Projects for Solar Heating and Cooling Components", Task II, IEA Dec., 1980

3) Hayashi, H., et al., "Survey and Review of Natioal R \& D Plans for Solar Heating and Cooling", Task II, IEA, Oct., 1981

4）たと党ば新エネルギー技術開発情報調査一太陽 編, 日本産業技術振與協会, 昭和 57 年 3 月

\section{5 海洋エネルギー利用技術の動向}

国土の12倍といら広大な経済水域を持ち，しかも消 費するエネルギーの大半を輸入する日本の場合，国内 に豊富な海洋エネルギーの利用技術を重視するのは当 然のことと思われるが, その可能性については一部専 門家を除き，一般にあまり認識されていない。

昨年以降の技術開発の進展を各海洋エネルギー別に 述べる。

\section{1. 波力発電}

世界で最も進んでいる日本の波力発電技術の開発 
は, I E A の国際協力研究となり，80年 5 月に，日本 海に打海洋䒠験を完了したことは昨年述べた。 81 年度はそれを担当した，(財) 海洋科学技術センター で, 実験データの理論的解析やそれに基づく水槽モデ ル奉験などが行われ，次の実験のため「海明」の改装 計画が進められている。その要点は，1. 波のエネルギ 一利用効率を上げるため, 空気室に底をつけ, 舷側に 開口部を設ける。2. 日本海の冬の卓越波に共振させる ため船長を $80 \mathrm{~m}$ から $120 \mathrm{~m}$ に延長する。3.船体と波の 振動が逆位相の時に最も変換効率が大きくなるので, 弁の開閉などに位相制御機能を持たせる。4. 空気ター ビンの改良，とくに空気の流れ方向が逆になっても回 転方向が変らぬウェルスタービンの採用, などである。

また企業ベースでもいくつかの小規模開発が進めら れており, 日立造船のペンジュラム方式は北海道で海 上実験を行った。

昨年度の年報で述べた如く, 英国は 8 つの方式を取 りあげ開発を進めて来たが，経済性と大幅に変動する 海洋環境に打ける寿命の二点を重視した中間評価を行 い, 5 つを中止し, 残りの 3 方式について目下進行中の 実海域でのモデル試験の結果をみて，どの形にしぼる かをきめることになったが，結論は未だ出ていない。 昨年もふれたことであるが，米エネルギー省はダム ・アトール方式を支援して和り，さらにモデルを50分 の 1 スケールに大型化する 2 年間の開発研究をロッキ 一ド社に委託した。目下研究が進められている。

\section{2. 海洋温度差発電 ( O T E C)}

日本の国ベースのサンシャイン計画の第 2 次計画に よれば，O T E C 開発は，82年度から 100kW 級のテス トプラントの建設に入る予定になっているが，80年度 に和於る開発体制の変更などで, 準備がおくれ, 予定 の82年度着工はみ和くられた。しかしながら, 他方工 技院電総研に护る研究計画は順調に進んでいるの で，今後の着工の期待は出来よう。

これに対し，民間ベースの開発は活発である。すな わち東京電力, 東電設計は中部太平洋, 赤道直下のナ ウル共和国に定格出力 $100 \mathrm{~kW}$ のO T E C 実験プラント (陸上型) の建設を就わり，80年10月から運転を開始 した。東京芝浦電気が発電システムの最適設計, コン ポーネントの設計，製作，据付運転を担当した。また 総延長 $950 \mathrm{~m}$ に及ぶ深海水取水管（ポリエチレン, 内 径70cm）の工事などは清水建設が担当した。10月以降 3 ケ月にわたり発電試験を行い, きわめて安定で, 故 障なく，当初計画を上回る効率で運転された。最大出 力 $120 \mathrm{~kW}$ (取水ポンプなどの所内動力を差し引いた正
味出力 $31.5 \mathrm{~kW}$ ) や, 昼夜連続10日間, 出力 $105 \mathrm{~kW}$ (正味 出力14kW)-計画出力は $100 \mathrm{~kW}$ (正味11. 1kW)一などに成 功した。これらは出力でも，連続運転時間でもこれま での記録，米国の MINI-OTEC の倍以上の記録を収 め日本の技術を改めて世界にP R したともいえよう。 作動流体はフロン22 (米国はアンモニア), 熱交換器 は高伝熱特性を持たせるため, 外側を特殊加工したチ ニーブ (Ti)/シェル型のもので，ボール洗浄装置を組 又合せることによって海水中の污染による伝熱特性の 低下を避けることにも成功した。引き続き 82 年秋まで 試験が継続される予定である。

また九州電力は佐賀大学の協力を得て, 82年に出力 $50 \mathrm{~kW}$ 発電実験を行らため準備中である。

米国では80年秋 O T E C -1とよぶ，米海軍の油槽船 を改造したO T E C 実験船が完成し，80年12月から81 年 4 月までの間，ハワイ島沖で海上実験を行った。熱 ループとしては電気出力 $1,000 \mathrm{~kW}$ に相当する大型のも のであるが, タービン／発電機を持たないので発電は 行わない。日本のそれの約10倍の大型のチューブ(Ti) ノシェル型熱交換器を主要素とする熱ループ（作動流 体アンモニア）の実海洋での試験と大型冷海水取水管 （ポリエチレン，内径 $1.2 \mathrm{~m} \times 3$ 本，長さ $700 \mathrm{~m}$ ) の海 洋施工，耐久試験が主体であった。政権交代の影響を 受け，予算が削られ試験期間は4 ケ月に短縮されたが， 長期間の性能試験を除きおおむお試験を完了し，81 年 6 月ワシントンで開催された第 8 回海洋エネルギー 会議（エネルギー省主催）で報告された。なおこの会 議では150篇（昨年の約1.5倍）のO T E C 実施につな がる具体的問題を主体とする報告がなされ，また $40 \mathrm{M}$ W級までのOTE C プラントの建設に必要な技術はほ ぼかたまったといらコンセンサスも得られた。

O T E C 研究開発㐨よび実証法（昨年年報参照）に もとづき，米ェネルギー省は 10/40MW 級のパイロッ トプラント開発プランの提案を民間に求めた。締切の 81 年 2 月末には 8 つのグループからプランが提出され た。

これらの提出の内，2つは海洋型であるが，残りの 5 つは陸上設置ないしは水深 $100 \mathrm{~m}$ 以浅の浅海底に基 礎を置く半水汲式櫓型である。OTE C に必要な技術 のらち, 現段階では送電拈よび係留技術の開発が最も 遅れているので，リスクを避けるためにとられた方策 とみられよう。

しかしこの計画のフェーズ 1 および 2 つの実施予算 を含んだ，F Y 82年度のOTE C 関係予算は政権交代 の影響を受け，流動的で，ようやく81年12月レーガン 
大統領の署名により，\$20.8M（要求は $\$ 25 \mathrm{M} ）$ 飞き まったので, 今後の進展は期待出来よう。

国際連合は 81 年 8 月ナイロビで,「新および非消隇 エネルギー会議」を開催した。国連は各種海洋エネル ギ一の内, 発展途上国向には, 小型(数千 $\mathrm{kW}) \mathrm{OTE} \mathrm{C}$ 発電プラントに造水や深海水利用養殖システムを組み 合せた多目的システムを推進しょうとしている。なお この種の多目的システムに関し, 第 8 回海洋エネルギ 一会議で, 国連, 米, 日拉よびスウェーデンから計 8 件の発表があった。

\section{3. その他の海洋エネルギー}

黑潮のエネルギーを利用する海流発電システムを (財)科学技術センターが中心で, 電力会社の協力の形 で進められている。海中係留式のプロペラ水車型で, 理論解析, 水槽モデル実験, 三宅島沖等どを想定設置 地点とするシステム検討などである。

また国外ではイタリア（シシリ一海峡，水車型，海 底設置) やカナダ（サポニアス水車型）などで検討さ れている。水車トルクは流速の 2 乗に比例するので, 流速 6 ノットに及ぶ三宅島沖やシシリー海峡のような 地点では可能性が考光られる。

潮汋発電はフランスがランス発電所（最大出力 24 万 kW）で15年にわたる実用実績を持つ以外は，ソ連にお ける実験発電所, 米, 加に和けるシステム検討段階で, いづれも実用プラントには着手していない。昨年は英 国，韓国でも構想が発表された。

海洋バイオマスエネルギー利用は78年以来, 米国ガ ス協会の資金で，GEがロスアンゼルス南の海域で実 験を継続している。深海水をポンプで汲み上げ，それ に含をれる栄養塩を生育速度の大きな $(60 \mathrm{~cm} / \mathrm{d})$ ）ジ アイアント・ケルプを育生する研究で, 技術的には有 望な結果を得ているが，経済性を論ずる段階には到っ ていない。

\section{6 バイオマス燃料の動向}

近年化石燃料, 特に石油の高騰と将来予想される枯 渴借总, バイオマス資源の有効利用が注目されてい る。バイオマスは再生産可能な資源として有望である が，これから然料を生産するためには複雑なプロセス を必要とする。バイオマスから得られる燃料としてフ ルコールなどの液体燃料と水素やメタンのガス状然料 があり、これらを総称してバイオマス燃料という。こ
のバイオマス燃料を生産する多くの方法が試みられて いるが，微生物や酵素を用いる生物化学プロセスでこ れを燃料に変換するプロセスが，省エネルギーで無公 害のプロセスとして注目されている。ここではバイオ マス燃料の最近の動向について述べる。

\section{1. エタノール}

ブラジルでは約 400 万 $\ell$ の業用アルコールが生産 され，これとガソリンを混合して（これをガソホール (Gasohole) と称している) 自動車燃料に利用してい る。このブラジルのエタノール生産量は, わが国の生 産量の25倍であり，いかにブラジル政府がこのブロジ ェクトに力を入れているかがわかる。アメリカでも大

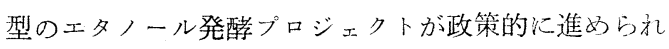
て㧍り，アルコールを生産してこ机をガりリンと混合 して市販している。このエタノール生産の原料を何に するかは重要な問題で㐫り, 各国とも光の国特有の農 産資源をそれに当てているょらである。たと党ばドイ ッでは, バレイショ,ブラジルでは甘しょ糖と糖みつ, 米国ではトウモロコシなどが主原料となっている。

わが国でも1980年代の最重要政策として石油に代る 新エネルギー開発が打ら出され, アルコール発酵もそ のひとつに選定され, 安価かつ大量にェタノールを生 産するプロセスの開発が進められている。わが国のよ らにせまい国土では農産資源も乏しいので, アルコ一 儿発酵の原料を広範囲に求め; 少ない:゙イオマスを有 効に利用しなければならない。この原料として考光ら れるのは, 糖質系バイオマス, デンプン質系バイオマ ス，セルロース系バイオマスなどである。糖質系のバ イオマスは，これに酵母などを作用させるとこれを直 接ェタノールに転換できる。デンプン質系バイオマス の場合には，これを市らかじめ液化，糖化して微生物 の資化可能なグルコースなどに変換しなければならな い。そこでいかにデンプンを効率的に液化，糖化する かが問題であり, 固定化グルコアミラーゼの利用なぞ も検討されている1。セルロース系バイオマスとして アフリカに生育する熱帯性牧草のエレファントグラス （ネピアグラスともいら）が注目されている。この植 物の収量は, $50 \sim 150 \mathrm{t} / \mathrm{ha}$ とされて拈り, きわめて収 量が高く有望なバイオマスとして注目されている。わ が国の場合にはこのような一般のセルロース系資源の 他に未利用繊維物質や廃棄物の利用を積極的に進めな ければならない。

さて，これらのセルロース系バイオマスは，いずれ る酸や酵素を利用して糖化しなければならない。これ らの糖化率を上げるため前処理方法や糖化処理条件の 
検討が盛んに行われている。糖化方法として最も注目 されているのは，七ルラーゼによるセルロースの加 水分解である。そこでセルラーゼ生産能の高い微生物 の検索および育種が精力的に行われている。たとえ

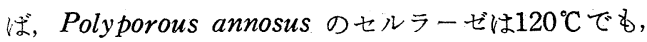
活性を有するため, 耐熱性の $\alpha$ アミラーゼと併用する ことにより，デンプン系バイオマスを高温蒸者するこ となく効率的に糖化することがでさる2)。またキャッ サバには，繊維質が1.7〜3.8\%ぐらい含まれており， これを糖化するのに Trichoderma viride のセルラー ゼを添加すると資化糖の収率が 7 ～8\%も増加するこ とが報告されている3゙。材繊維ではセルロースがリ グニンと共にリグノセルロースの形で存在するので, これを直接セルラーゼで分解するのはむずかしい。し たがってリグニンを效率的に除去する必要があり， ア ルカリや酸による化学的前処理や微粉研，凍結粉砕な ぞによる物理的前処理が必要である。最近微生物を用 いてリグニンを除去するために強力なリグニン分解菌 の検索や育種（組又換觉D NA技術の利用も含む）が 進められている。

従来から工業的にアルコール生産菌として酵母が利 用されているが, 増殖速度が速く, 高収率でアルコー ルを生産できる微生物の検索とDNA組み換え技術を 利用した育種が盛んに行われている。たとえば，テキ 一ラ発酵菌として有名な Zymomonas mobilis の利用 が注目されている。 Rogersらは Zymomonas mobilis を用いて酵母よりも高収率でアルコールが生産できた と報告している。すなわち彼らは発酵槽から流出する 菌体を連続的にミリポアフィルター（塩化ビニル製, 孔径0.6 $6 \mu \mathrm{m}$ ）で分離して再び発酵槽にもどしてェタ, 一ル発酵に使用した。菌体の返送を低菌体濃度から始 め, 次第に稀釈率学高めた。この稀釈率が $2.7 \mathrm{~h}^{-1}$ の時 は, 菌体濃度は $38 \mathrm{~g} \cdot \ell^{-1}$ となり, エタノール濃度は 44.5 $\mathrm{g} \cdot \boldsymbol{l}^{-1}$ であり, 最大エタノール生産率は $120 \mathrm{~g} \cdot \boldsymbol{l}^{-1} \cdot \mathrm{h}^{-1}$ て あっだう。Zymomonasは酵母に比較して発酵速度が速 く，酵母よりやや高温でアルコール発酵を行らこと ができる（表9-8）。さらに高温菌を検索してエタノ一 ルの生成速度を上げ蒸留のコストを下げる研究も行わ れている。しかしこの菌は糖類資化範用がせまいので, これを育種するために Zymomonas 属細菌のプラス ミッドの研究が進められている5 。将来は遺伝子組み 換え技術を利用して，セルラーゼやアミラーゼ活性を 有する耐熱性のZymomonas 細菌を育種することも可 能となろらと考えられる。なお Zymomonas 細菌によ るアルコール発酵に関しては総説もあるので詳細はそ
表 9-8 Z. mobilis と S. carlsbergensis のハ ッチ方式によるエタノール発酵（グルコース $25 \%$ )

Z. mobilis S. carlsbergensis

\begin{tabular}{lll}
\hline 比増殖速度 $\left(\mathrm{h}^{-1}\right)$ & 0.13 & 0.055 \\
グルコース代謝 & 5.5 & 2.1 \\
$\begin{array}{l}\text { 速度 }(\mathrm{g} / \mathrm{g} / \mathrm{h}) \\
\text { エタノール生成 }\end{array}$ & 2.5 & 0.87 \\
\begin{tabular}{l} 
速度 $(\mathrm{g} / \mathrm{g} / \mathrm{h})$ \\
\hline
\end{tabular}
\end{tabular}

れを参照されたい66。

さらにデンプンまたはセルロースの直接発酵による エタノールの製造が考光られている。すなわちセル口 一ス系農林産廃棄物に Clostridium thermocellum を 作用させ，セルロースから直接エタノールを連続的に 発酵生産させる試みがある。たと学ば，1.5〜3\%の純

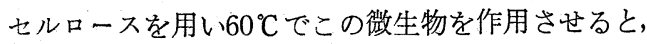
$0.3 \sim 0.9 \%$ のタノール濃度が得られている7。この 場合のエタノールの収量は $0.3 \mathrm{~g} \cdot \mathrm{g}^{-1}$ 消費セルロース であった。

その他高温性のエタノール産生菌を検索し, 高温で エタノールを蒸発させながら発酵を行い，生成物を阻 害（エタノールにより微生物活性が低下する）を防止 したり,エタノールの蒸留に必要なコストを下げる試 みもなされているよらである。

一方ェタノ一ル産生酵母を固定化し，これを用いて エタノ一ルを生産させる試みもある。すなわち, 千畑ら は, Saccharomyces carlsbergensisを たーカラギーナン ゲル中に固定化し，このゲル中で酵母を増殖させてエ タノールを生産させ, グルコースから $50 \mathrm{~g} ・ \ell^{-1} \cdot \mathrm{h}^{-1}$ の速 度でエタノールを生産させることに成功している8 。 また Munnecke らは酵母をアルギン酸カルシウムゲ ル中に固定化し，これを充填槽に入れ，53. $8 \mathrm{~g} \cdot \ell^{-1} \cdot \mathrm{h}^{-1}$ のアルコールを連続的に生産している9 。

\section{2. ハイオガス}

水素やメタンなどのバイオガスをバイオマスから 生産する研究も最近盛んである。特に以前から廃棄物 処理工程で実用化されていたメタン発酵は積極的なエ ネルギー生産プロセスとして見直されており，世界的 に盛んに研究が行われて和り，廃棄物バイオマスのエ ネルギー化に重要な役割をはたするのと期待されてい る。一方，水素はクリーンなエネルギーとして注目さ れて扣りバイオマスから水素を生産するプロセスも重 要である。この分野に和ける最近のトピックスは組み 換えDNA技術を利用したヒドロダナーゼのクローニ ングである。この研究は世界的な競合状態にある。こ 
こでは光エネルギーを利用して水素を生産する光合成 微生物に焦点を合わせて水素の生成について述べる。

光合成微生物による水素生産は菌体内で行われる光 合成系と連結して和り，これを水素の生産として利用 すれば新しい太陽エネルギー 利用システムとなり得 る。実際に光合成微生物を利用した水素生産は次のよ らな利点をもっている。すなわち，1）常温で反応が進 行する。2)系に必要なものは, 太陽光と水素源（水な ぞ）のみである。3)化石燃料を精製する時のような派 染物質の発生を伴わない。4)微生物は食糧, 医薬品な ぞの生産やメタン生産菌の栄養源など多目的に利用で きる。

さて, 海水中には光合成微生物の生育に必要な栄養 が多く含まれている点を考えると海洋性の光合成微生 物を利用することは有効と考えられる。

微生物を利用した光水素生成は1942年に Gaffron, Rubbinらが緑藻で10)，1949年に Gest, Kamen らが 光合成細菌で行わせたのがはじまりである1112)。それ 以後, 水素発生機構の研究がすすめられ, 培養条件の 調整, 代謝阻害剂の使用, 酸素などの酸化剂の除去と 反応条件が確立され，高い水素生産が達成されるに至 っている。

一方，生菌体による水素生成速度は遅いことから， 細胞抽出液を用いた無細胞系による水素生成も試みら れている。1961～63年に三井らは，植物の葉緑体， メ チルビオロゲン，ヒドロゲナーゼを組み合わせた水素 生産システムを構成することに成功している ${ }^{13)}$ 。水素 生成機構に関与する成分をあつめて抽出状態で安定化 させることが必要であり，筆者らはこれらを高分子ゲ ルマトリックス中に固定化し, 安定化をはかっている。

マイアミ大学の三井らは, 高い水素生産能をもつ熱 帯海洋性光合成微生物の探索を精力的に行い大きな成 果をあげている。すでに, 有望な水素生産能をるつ菌株 を分離し, 水素生産, 増殖の最適条件を確立している。

通常，らん藻による水素生成速度は，0.2 100 $\mu \mathrm{mol}$ $\mathrm{H}_{2} \mathrm{mg}$ ch $\ell^{-1} \mathrm{day}^{-1}$ であるが, 三井らは, カリブ海より $260 \mu \mathrm{molH} 2 \mathrm{mg} \mathrm{ch} \ell^{-1} \cdot \mathrm{h}^{-1}$ の速度で水素を生成するら 九藻 (Oscillatoria sp., 通称 Miami BG 7) を発見 した ${ }^{14)}$ 。Miami BG7 はニトロゲナーゼによる水素 生成活性が特に高く，水素吸收のみを一方的に触媒す るアップティクヒドロゲナーゼとよばれるヒドロゲナ 一ゼを欠くため，長期間にわたり高水素生成能が維持 される。三井らが得ている Miami BG 7 の水素生成 の最適条件をここに紹介する。

前培養として咥素源を抑えた培地で12日間培養した
藻体について水素生成速度を測定したところ，少量の $\mathrm{KNO}_{3}\left(5 \mathrm{mg} \cdot \ell^{-1}\right)$ を含む場合に最も高い水素生成能が 得られた。この条件で前培養した藻体を窒素源を含ま ない培地中に移して炭水化物, タンパク質, クロロフ ィル量の推移扣よび水素と酸素の発生量を調べた。そ の結果, タンパク量はほぼ一定だったのに対し, 炭水 化物含量は増加した。また，乾重量当りのクロロフィ ルaの含量も0.6\%から0.1\%に低下した。この場合の 炭水化物の増加は, 電子供与体として働く生体内基質 が蓄積したことを意味し， $\mathrm{C} / \mathrm{N}$ 比の増大はニトロゲ ナーゼの合成を促進すると考学られる。またクロロフ ィルの減少は光化学系II の活性低下を意味し, 酸素発 生量の低下が起り, その結果として酸素によるニトロ ゲナーゼの活性阻害が減少したと考兄られる。酸素, 水素発生量の推移はこの推察を裏つけており, 培湌 8 日目になると酸素発生量が大幅に減少, 最大水素生成 速度は260 $\mathrm{molH}_{2} \mathrm{mg} \mathrm{ch} \ell^{-1} \cdot \mathrm{h}^{-1}$ に達した(図9-10)。

三井らは, このMiami BG7を用いる水素生産につい て興味ある試算を行っている。これによれば,フロリダ 州の平均的家庭が夏季に消費する $1,000 \mathrm{kWh}$ •月 ${ }^{-1}$ の 電力に相当するエネルギーをらん藻が生成した水素か ら得るためには， $1 \mathrm{~m} \times 8 \mathrm{~m} \times 8 \mathrm{~m}$ の容積の池でB G7を 培養すればよい(15)。このように，高い水素生産能をも つらん藻は将来エネルギー生産システムとして実用化 される可能性が大きい。
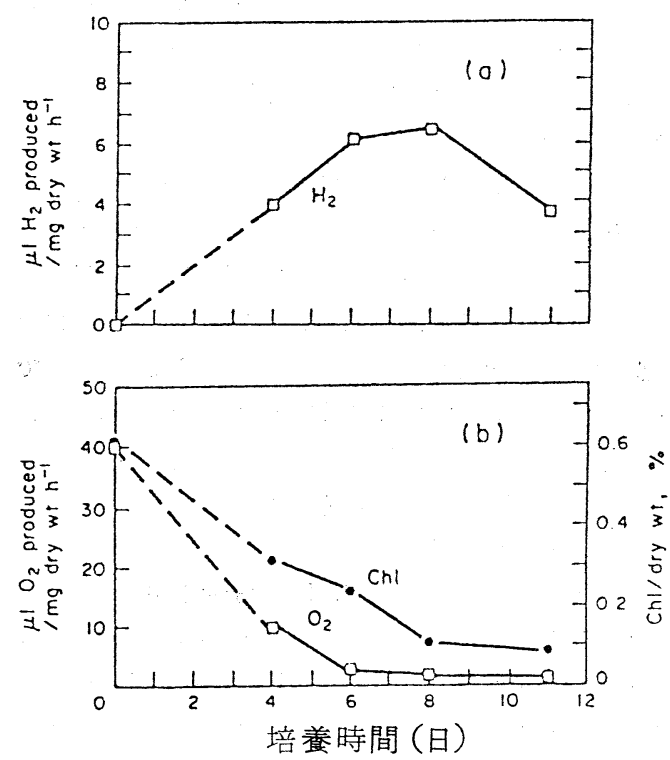

図 9-10 海洋性らん藻 (Miami BG 7) における光水素生成量, 酸素生成量 とクロロフィル含量の関係 
一方, 光合成細菌はらん藻と異なり光化学系の I のみを有する圲め酸素の発生はないが，やはり二ト ログナーゼの副反応で水素を生成する機構を有して いる。光合成細菌には生育にイオウを要求するもの としないものがあり硫化水素や有機化合物を基質と 乙て生育し, 水素を発生する。三井らは高い水素生 成能をもちかなり速く增殖するイオウ性光合成細菌 (Chromatium sp. Miami PBS1071) を発見し, その生育条件の最適化を図った ${ }^{16)}$ 。

Miami PBS 1071 は, 分裂時間が 1.75 時間と非 常に速く, 有機化合物の資化性子幅広く, 多くの有 機化合物から炭素と䇪素を取りこむことができる。 また，酸素による増殖の阻害もらけにくく，3\%の 酸素存在下でも水素生成能は $50 \%$ 乙か阻害をうけな い点が注目される。

一方, 光と温度に関する最適条件はそれぞれ $150 \mu$ Einstein $\mathrm{m}^{-2} \mathrm{~s}^{-1}$ と $34^{\circ} \mathrm{C}$ で比較的高い值であり, 亜 熱带地方での実用化に適していると考光られる。

この菌株による水素生成の最適化の検討も進めら れて扣り, 現在までにコハク酸塩とチ才硫酸塩を基質 として対数增殖期に $6.0 \mu \mathrm{molH}_{2} \mathrm{mg}$ protein ${ }^{-1} \cdot \mathrm{h}^{-1}$ の 水素生成速度が得られている ${ }^{17)}$ 。(図9-11)。

以上最近の報告を中心にバイオマス燃料の動向につ いて述べた。わが国でもバイオテクノロジーの進展に 伴い, バイオマス燃料の実用化が行われる日もとう遠 くないと思われる。

\section{文献}

1) Maeda, H., et al., J. Ferment. Technol., 57, 238 (1979)

2) DeMenezes, T. J. B., Process Biochem., 13 (Sep), 24 (1978)

3) DeMenezes, T.J.B., et al., Biotechnol. Bioeng., 20, 555 (1978)

4) Rogers, P. L., et al., Process Biochem., 15 (Aug/Sep), 7 (1980)

5) Skotnicki, M.L., et al., Appl. Environ. Microbiol., 40, 7 (1980)

6) Swings, J., et al., Bacteriological Reviews,

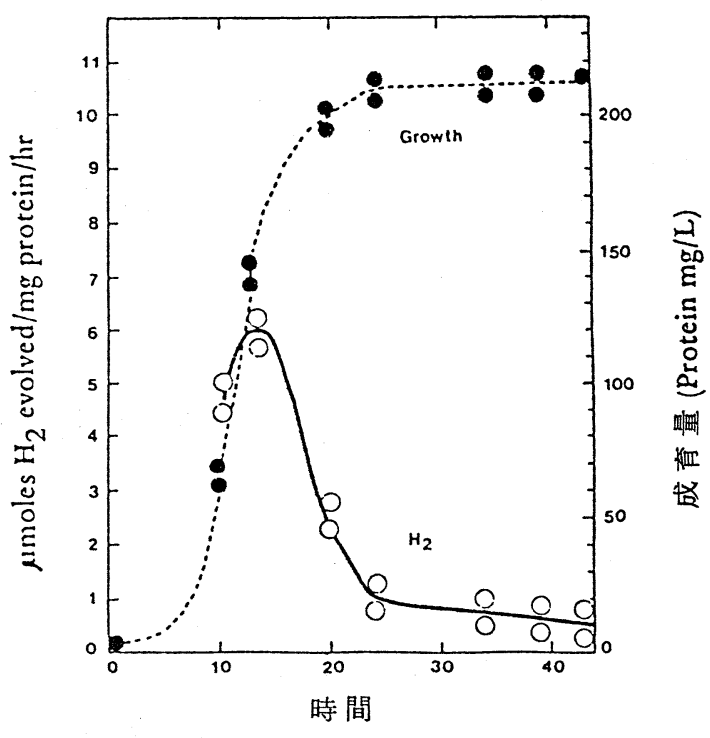

図 9-11 海洋性光合成細菌 (Miami PBS 1071) の増殖曲線と水素生成量の関係

41, 1 (1977)

7) Zertuche, L., et al., Biotechnol. Bioeng., 24, 57 (1982)

8) Wada, M., et al., Eur. J. Appl. Microbiol. Biotechnol., 10, 275 (1980)

9) Williams, D., et al., Biotechnol. Bioeng., 23, 1813

10) Gaffron, H., et al., J.Gen. Physiol., 26, 219 (1942)

11) Gest, H., et al., J. Bacteriol., 58, 239 (1949)

12) Gest, H., et al., Science, 109, 558 (1949)

13) Arnon, D. I., et al., Science, 134, 1425 (1961)

14) Kumazawa, S., et al., Int. J. Hydrogen Energy, 6, 341

15) Mitsui, A., Hydrogen Energy system, Vol. 3, Pergamon Press. Oxford, p. 1267 (1978)

16) Ohta, Y., et al., Int. J. Hydrogen Energy, 6, 451

17) Ohta, Y., et al., Advances in Biotechnology, Vol. II, Pergamon Press, Toronto, p. 303 